\title{
The molecular mechanisms of hypoglycemic properties and safety profiles of Swietenia macrophylla seeds extract: A review
}

\author{
Ratih Dewi Yudhani ${ }^{1,2 *} \mathbb{C}$, Dwi Aris Agung Nugrahaningsih ${ }^{3} \mathbb{C}$, Eti Nurwening Sholikhah ${ }^{3}$, Mustofa Mustofa $^{3}$ \\ ${ }^{1}$ Department of Pharmacology, Faculty of Medicine, Universitas Sebelas Maret, Surakarta, Indonesia; ${ }^{2}$ Doctoral Programs in Health \\ and Medicine, Faculty of Medicine, Public Health and Nursing, Universitas Gadjah Mada, Yogyakarta, Indonesia; ${ }^{3}$ Department of \\ Pharmacology and Therapy, Faculty of Medicine, Public Health and Nursing, Universitas Gadjah Mada, Yogyakarta, Indonesia
}

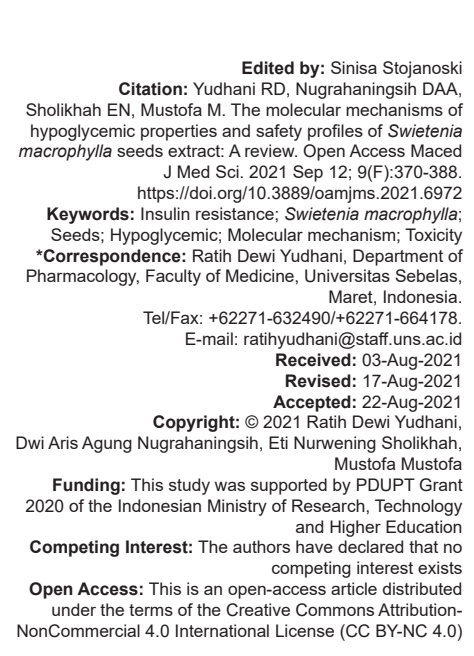

\section{Introduction}

Diabetes mellitus (DM) is still a global health burden and is listed among the ten most common causes of death worldwide. In 2017, the number of diabetic incidences reached 425 million and was estimated to increase to over 629 million by 2045 . Most cases of DM are found in low- and middle-income countries, including Indonesia, where the diabetic population has reached 10.1 million [1], [2]. Chronic hyperglycemia is prone to increase the risk of various complications, including cardiovascular disease, diabetic neuropathy, and nephropathy, resulting in a low quality of life and tremendous economic and social burdens, as well as mortality and disability worldwide [1], [3], [4].

There are two major types of diabetes. Type 1 diabetes is an autoimmune disorder related to pancreatic $\beta$-cells injury and leads to insulin secretion deficiency, while type 2 diabetes (T2D) is affected by a combination of genetic factors associated with impaired insulin secretion, insulin resistance (IR), and environmental factors [5], [6]. Around $90-95 \%$ of diabetes incidences is T2D with the $\beta$-cells dysfunction and IR as the underlying pathogenesis [3], [4]. IR is define as a condition when insulin targeted tissues do not respond adequately to insulin stimulation, which leads to hyperglycemic conditions and initiates T2D [7], [8]. At the cellular level, it refers to dysregulation of the insulin signaling pathway in insulin-sensitive tissues (muscle, liver, and adipose tissues) [7], [9]. Hence, IR causes impairment of glucose uptake and reduction of glycogen synthesis while increasing hepatic gluconeogenesis and lipolysis. This leads to the elevation of free fatty acids (FFA) and glycerol [10]. IR is considered the main underlying factor for the development of metabolic syndrome and has become a substantial therapeutic target in T2D [11], [12].

Metformin and pioglitazone are widely prescribed drugs for improving insulin sensitivity. However, both have some side effects and various contraindications, and their long-term efficacy has not 
been proven yet. Hence, it is necessary to develop more drugs targeting IR based on a deep understanding of its pathogenesis [11], [13].

Herbal remedies serve as a great source and play a pivotal role in traditional diabetes treatment [14]. Nowadays, many studies are focusing on herbal remedies based on phytochemicals, presenting as potential antidiabetic candidates and targeting IR pathways [11], [12], [15]. Even though many oral diabetes agents are available, diabetes and its complications continue to rise. Hence, the World Health Organization suggests the exploration and development of natural ingredients as an alternative diabetes therapy [16]. Referring to the world ethnobotany report, about 800 medicinal plants, including Swietenia macrophylla, are used as traditional treatments for diabetes, since they are considered to have better efficacy with fewer side effects, and are affordable [16], [17], [18].

S. macrophylla seeds extract has become of great interest and has been used as a traditional diabetes treatment in many Asian countries, including India, Malaysia, and Indonesia. Moreover, its hypoglycemic activities are supported by evidence from experimental studies [15], [18], [19], [20], [21], [22]. The methanol extract of $S$. macrophylla seeds has the ability to decrease fasting blood glucose as well as to decrease total cholesterol and triglyceride in a T2D rats model [19]. Swietenine from S. macrophylla seeds was reported to lower fasting blood glucose levels and improve liver glycogen content in streptozotocin (STZ)-induced diabetic rats [20]. The aqueous extract of S. macrophylla seeds also has the ability to reduce blood glucose, modulate the lipid profile, and restore $\beta$-cells function without altering any histopathological structure of liver and kidney tissues in the diabetic rats [21]. Nevertheless, the molecular mechanisms of those properties have not been clearly elucidated yet. This review attempts to provide a comprehensive understanding of the molecular mechanisms underlying the hypoglycemic properties of S. macrophylla seeds extract as well as to assess its safety profile.

\section{Methods}

An extensive search of the literature was conducted. The most of collected sources were screened from four main databases - PubMed, Scopus, Science Direct, and Google Scholar - using several keywords: "swietenia macrophylla, seeds, diabetes;" "swietenia macrophylla, seeds, oxidative stress;" "swietenia macrophylla, seeds, inflammation;" "swietenia macrophylla, seeds, GLUT4;" and "swietenia macrophylla, seeds, toxicities". The journals as sources for this review were not limited by year, but most of the references (more than $85 \%$ ) were published in the past 10 years.

\section{Results and Discussion}

\section{Botanical, ethnomedical and phytochemical constituents of S. macrophylla}

Botanical and ethnomedical of S. macropylla

S. macrophylla (Figure 1) is a folk medicinal plant belonging to the family Meliaceae and commonly called Cheria mahogany in Malaysia and mahoni in

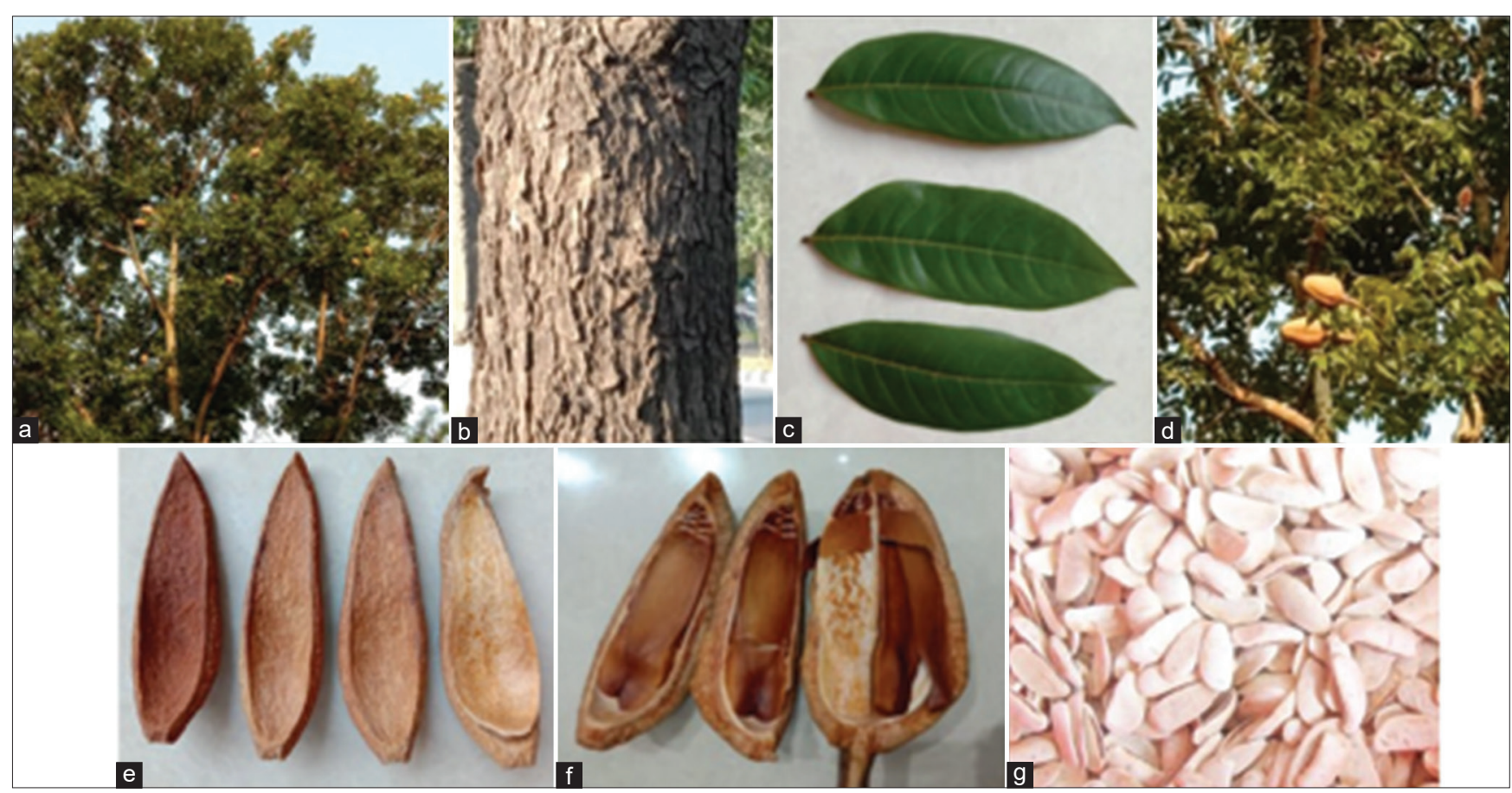

Figure 1: Swietenia macrophylla King. The tree (a), bark (b), leaves (c), fruits (d), capsules (e), seeds with capsules (f), seeds (g) 
Indonesia. S. macrophylla is an indigenous plant from Brazil, Mexico, Bolivia, and other central American countries [15], [18], [22], [23].

In some Asia and African countries, S. macrophylla has been used traditionally to treat many diseases, such as diarrhea, hypertension, malaria, and diabetes. It is also known to have pharmacological properties, including antimicrobial, anti-inflammatory, anti-oxidant, and anticancer effects [18], [22], [24], [25]. As folk medicine, the $S$. macrophylla seeds have medicinal activities, particularly to treat diabetes and hypertension in Malaysia and Indonesia [18].

\section{Phytochemical constituents of S. macrophylla seeds}

The main phytochemical constituents of S. macrophylla seeds are limonoids and other compounds, such as polyphenols, steroids, and fatty acid ester. Limonoids are derived from tetracyclic triterpenes and tetranortriterpenoids [18]. There are many other derivates of tetranortriterpenoids isolated from S. macrophylla seeds, including swietinine, swietenolide, 6-O-acetylswietenolide, and swietenolide diacetate [18], [22], [23], [26].

In addition, $S$. macrophylla seeds contain flavonoids, alkaloids, saponins, and tannins as their main compounds [27]. Phytochemical screening [28] revealed that the crude extract of $S$. macrophylla seeds contains major phytoconstituents, such as alkaloids, terpenoids, and carbohydrate. There were also other active compounds, including flavonoids, saponins, tannin, and steroids [28].

\section{seeds}

\section{Hypoglycemic activities of S. macrophylla}

Numerous evidences support the hypoglycemic properties of $S$. macrophylla seeds extract that has been proven through previous in silico, in vitro, and in vivo studies. We attempt to discuss the findings from several prominent publications as summarize in Table 1.

\section{In silico studies of hypoglycemic properties of S. macrophylla seeds}

In line with the rapid advancement of computerized technology, the latest drug development process for identifying and enriching the structure of the active compound candidate can be conducted through computerized in silico tests. It can also analyze the pharmacological mechanisms of medicinal plant candidates. Hence, this procedure shortens the study periods, saves costs from the random screening process, and makes drug-discovery pipelines more effective [39], [40].
Table 1: Hypoglycemic properties of Swietenia macrophylla seeds extract

\begin{tabular}{|c|c|c|}
\hline Research & Results & References \\
\hline \multirow[t]{2}{*}{ In silico } & $\begin{array}{l}\text { 1,4-bis-(3,4,5-trimethoxy-phenyl)-tetrahydro-furo(3,4-c)furan } \\
\text { (saponins isolate) from } S \text {. macrophylla seeds extract should } \\
\text { has the strong hypoglycemic activity since it has the lowest } \\
\text { binding energy }(-97.29 \mathrm{kcal} / \mathrm{mol}) \text { to interact with proliferator- } \\
\text { activated receptor y }\end{array}$ & [29] \\
\hline & $\begin{array}{l}\text { Phytoconstituents from S.mahagony (swietenine, swietenolide, } \\
\text { mahonin, swietemahonolide, etc.) are potential as SGLT-2 } \\
\text { inhibitors in silico because they can bind to SGLT-2 with lower } \\
\text { binding energy }(-12.59 \mathrm{kcal} / \mathrm{mol} \text { to }-9.15 \mathrm{kcal} / \mathrm{mol}) \text { compared } \\
\text { to standard drugs dapagliflozin }(-7.77 \mathrm{kcal} / \mathrm{mol})\end{array}$ & [30] \\
\hline \multirow[t]{2}{*}{ In vitro } & $\begin{array}{l}\text { 6-O-acetyl swietenolide, diacetyl swietenolide and swietenine } \\
\text { from S. macrophylla seeds induced GLUT4 membrane } \\
\text { translocation in C2C12 muscle cells which led to glucose } \\
\text { utilization }\end{array}$ & [26] \\
\hline & $\begin{array}{l}\text { The SMEAF improved the cell viability and showed protection } \\
\text { of rat's primary neuronal culture cell against oxidative stress } \\
\text { induced by tert-butyl hydroperoxide }\end{array}$ & [31] \\
\hline \multirow[t]{9}{*}{ In Vivo } & $\begin{array}{l}\text { Methanol extract of } S \text {. macrophylla seeds at dose } 300 \mathrm{mg} / \mathrm{kg} \\
\text { caused a significant decreasing }(59,69 \%) \text { of blood glucose in } \\
\text { STZ-induced diabetic rats model. It also reduces cholesterol } \\
\text { and triglyceride as well as increases glycogen contents in liver }\end{array}$ & [15] \\
\hline & $\begin{array}{l}\text { The alcoholic seeds extract of S. macrophylla leads to the } \\
\text { decreasing of blood glucose, improvement of body weight, } \\
\text { normalize the serum insulin and liver glycogen content in STZ- } \\
\text { diabetic rats model }\end{array}$ & [32] \\
\hline & $\begin{array}{l}\text { The treatment of S. macrophylla seeds petroleum ether extract } \\
\text { for } 14 \text { days resulted in a significant enhancement of abdominal } \\
\text { glucose utilization which leads to the reduction of blood } \\
\text { glucose on rats after intraperitoneal glucose tolerance test }\end{array}$ & [33] \\
\hline & $\begin{array}{l}\text { In vivo study on diabetic rat model documented that S. } \\
\text { macrophylla seed saponins isolate has the strongest effect in } \\
\text { lowering blood glucose levels }\end{array}$ & [34] \\
\hline & $\begin{array}{l}\text { Saponins isolated from S. macrophylla seeds extract was } \\
\text { able to reduce blood glucose significantly while increasing } \\
\text { pancreatic insulin expression in STZ-induced diabetic rat model }\end{array}$ & [29] \\
\hline & $\begin{array}{l}\text { Saponins isolated from S. macrophylla seeds extract has also } \\
\text { been proven to be able to decrease HOMA-IR significantly } \\
\text { which leads to insulin resistance improvement in a T2D rat } \\
\text { model }\end{array}$ & [35] \\
\hline & $\begin{array}{l}\text { Saponins isolated from S. macrophylla seeds extract had } \\
\text { glucose-lowering and antioxidant effects through reducing } \\
\text { malondialdehyde in STZ-nicotinamide induced diabetic rats } \\
\text { model }\end{array}$ & [36] \\
\hline & $\begin{array}{l}\text { 7-hydroxy-2-(4-hydroxy-3-methoxy-phenyl)-chroman-4- } \\
\text { one, flavonoids isolated from S. macrophylla seeds extract } \\
\text { reduced blood glucose by reducing HOMA-IR level and } \\
\text { phosphoenolpyruvate carboxykinase gene expression in a T2D } \\
\text { rat model }\end{array}$ & [37] \\
\hline & $\begin{array}{l}\text { The same flavonoids have the abilities to improve pancreatic } \\
\beta \text {-cell function through inhibiting the development of oxidized } \\
\text { low-density lipoprotein and increasing the expression of } \\
\text { glucagon-like peptide-1 }\end{array}$ & [38] \\
\hline
\end{tabular}

Several in silico studies have explored the phytoconstituents responsible for hypoglycemic activities of $S$. macrophylla seeds. The 1,4-bis-(3,4,5trimethoxy-phenyl)-tetrahydro-furo(3,4-c)furan isolated from $S$. macrophylla seeds should be expected for strong hypoglycemic activity due to its low binding energy $(-97.29 \mathrm{kcal} / \mathrm{mol})$ needed to bind on proliferatoractivated receptor $\gamma$ (PPAR $\gamma$ ). It is similar to $87.37 \%$ of the glibenclamide's energy in binding to PPAR $\gamma$ [29]. Glibenclamide is an oral hypoglycemic agent that works by improving insulin secretion from the pancreatic $\beta$-cell. There is evidence that glibenclamide not only works on the single target but also possesses as agonist PPAR $\gamma$ [41], [42].

PPAR $\gamma$ belongs to the nuclear receptors superfamily that regulates the expressions of proteins which involved in the uptake of fatty acid, lipid, and glucose metabolism, as well as insulin sensitivity [43], [44]. Compounds acting as PPAR ligands are an interesting focus in the development 
of T2D treatment because it suggests the ability to improve insulin sensitivity. The PPAR $\gamma$ agonists increase adipocyte differentiation and promote FFA uptake and storage, hence decreasing FFA plasma level. Moreover, PPAR $\gamma$ agonists increase both the expression and the membrane-translocation of glucose transporter 1 and 4 (GLUT1 and GLUT4), which facilitate glucose entry into the liver and skeletal muscle, respectively, thereby, lowering plasma glucose levels and improving insulin sensitivity [45]. Selective PPAR- $\gamma$ agonists are also known to increase insulin sensitivity by triggering insulin activity and amplifying insulin signals in insulin target tissues, hence reducing lipotoxicity and the release of pro-inflammatory adipocytokines [46].

Lipotoxicity is a crucial mechanism for the IR development in insulin-targeted tissues that triggers $\beta$ cell dysfunction. The pivotal metabolites that mediate lipotoxicity-induced IR is non-esterified fatty acids and triglycerides. The disruption of triglyceride metabolism in the liver and muscles in diabetics causing the formation of various secondary toxic compounds, such as fatty acylcoenzyme A, ceramides, and diacylglycerol (DAG). They serve as crosstalk between the tissues fats accumulation and hepatic IR by attenuating the insulin signaling pathway [46], [47]. Moreover, the role of lipotoxicity in triggering IR is related to its role in reducing mitochondrial oxidative capacity while inducing mitochondrial dysregulation and oxidative stress [48], [49].

PPAR $-\gamma$ has been shown to avert lipotoxicity, as evidence shows that there is a downregulation of PPAR- $\gamma$ expression in adipose tissue as well as an elevating of post-prandial triglyceride levels in both prediabetes and T2D subjects compared to the normal glucose tolerance group [50]. Clinical trials have also documented that the administration of PPAR- $\gamma$ agonist (pioglitazone) in 3 months reduces IR through decreasing fasting blood glucose and triglyceride in T2D patients [51]. This shows the crucial role of PPAR$\mathrm{Y}$ activation in modulating triglyceridemia, lipotoxicity, and the pathogenesis of T2D [50]. Interestingly, there has been evidence suggested that the PPAR- $\gamma$ agonists also reduce oxidative stress and inflammatory response, thereby restoring the metabolic shifting in diabetes [52].

A molecular docking study by Vigneshwaran and Lalitha (2017) was conducted to assess the inhibitory activity of phytochemical compounds from Swietenia mahogany Jacq. seeds extract toward sodium-glucose co-transporter (SGLT). It showed that Swietenine, Swietenolide, Mahonin, and Swietemahonolide substances in S. mahagony were potential as SGLT-2 inhibitor. They can bind to SGLT2 with a lower binding energy $(-12.59 \mathrm{kcal} / \mathrm{mol}$ to $-9.15 \mathrm{kcal} / \mathrm{mol})$ compared to the standard drug dapagliflozin $(-7.77 \mathrm{kcal} / \mathrm{mol})$. The lower energy needed to bind with the target indicate that those phytoconstituents have greater inhibitory activity compared to the reference drug [30]. Interestingly, S. mahagony Jacq. and S. macrophylla are two species belonging to the same genus "swietenia" [25].
There are two main types of SGLT: SGLT1 and SGLT2. The SGLT1 contributes to the glucose absorption process into the small intestine, whereas SGLT2 serves as a major transporter in the glucose reabsorption process in the renal tubules. Both transporters are considered important targets for the development of antidiabetic candidates [53].

Hyperglycemic conditions in diabetic patients enhance the reabsorption process of renal filtered glucose. The inhibition of SGLT2 in hyperglycemia normalizes blood glucose level by decreasing glucose reabsorption, followed by an increase in urinary glucose secretion. SGLT inhibition poses a promising strategy in diabetes treatment, since it also has an effect on reducing body weight and attenuating blood pressure [53], [54].

Several aforementioned in silico studies showed that the phytochemicals belonging to the genus Swietenia are promising in terms of their effects in modulating insulin signaling pathways, especially through PPAR $\gamma$ activation and SGLT2 inhibition. These preliminary findings support the idea that $S$. macrophylla seeds and its phytoconstituents have the potential to be further developed as a hypoglycemic candidate.

\section{In vitro studies of hypoglycemic properties of S. macrophylla seeds}

The bioactive compound screening to assess the potential biological properties of both extracts and molecules involves the series of processes, including molecular testing, cell-based testing (in vitro), and in vivo testing [55]. The success of drug discovery at pre-clinical steps is mainly determined by the ability of experimental models to represent the human pathophysiological process. In vitro efficacy testing in cellular models is used in this early stage because it is easy to characterize and adapt [56]. In vitro testing is also needed as one of the methods to validate targets that have been identified [57].

Collecting in vitro evidences have confirmed the potential hypoglycemic activity of S. macrophylla seeds and their phytoconstituents. The 6-O-acetylswietenolide, diacetyl swietenolide, and swietenine from $S$. macrophylla seeds promoted GLUT4 translocation, followed by excessive glucose uptake in the $\mathrm{C} 2 \mathrm{C} 12$ cell line [26]. The $\mathrm{C} 2 \mathrm{C} 12$ cell line is a muscle cell derived from a mouse that is most often used as an in vitro model to represent skeletal muscle [58]. It is an established cellular model that can be used to elucidate many biological processes, including glucose metabolism, insulin signaling, IR, oxidative stress, reactive oxygen species (ROS), and GLUT transporters at the cellular and molecular levels. The use of the $\mathrm{C} 2 \mathrm{C} 12$ cell line greatly supports the development of research, particularly in the drug discovery and biomedical fields, since it expresses GLUT4 and other characteristics that represent the physiology of human skeletal muscle [59],[60]. 
Lau et al. (2015) indicated that some of S. macrophylla phytoconstituents enhance glucose utilization in skeletal muscle cells, thereby modulating glucose levels. This activity is related to the PPAR $\gamma$ ligand properties possessed by the compound based on the ELISA modification binding test [26]. PPAR $\gamma$ is a gene transcription factor that regulated adipocyte differentiation, lipid storage, and glucose homeostasis [60]. Its activation causes the upregulation of adiponectin, which is known as a regulator of insulin sensitivity and energy homeostasis. PPAR $\gamma$ also a regulators of GLUT4 expression, which is responsible for glucose uptake [26]. This is likely to underlie the potential hypoglycemic activity of these phytoconstituents.

Another study revealed that the ethyl acetate fractions of S. macrophylla seeds (SMEAF) improved cell viability and protected rat's primary neuronal culture cell against in vitro oxidative stress model induced by tert-butyl hydroperoxide (TBHP) [31]. TBHP is an organic hydroperoxide compound that is often used as an oxidative stress inducer to increase the understanding of cellular and tissue responses in oxidative stress conditions. TBHP triggers oxidative stress through two pathways. The first pathway is related to cytochrome $\mathrm{P} 450$, which metabolizes TBHP and produces intermediates such as peroxyl and alkoxyl radicals that promote lipoperoxidation of phospholipids membrane. The second is associated with glutathione peroxidase (GSH), which detoxifies TBHP into tertbutanol and causes the depletion of GSH since it is oxidized into disulfide form (GSSH). Lipoperoxidation, the decreases of GSH levels, and increases in mitochondrial membrane permeability are considered common mechanisms of the cellular injury state caused by oxidative stress. These biochemical events support the acceptance of TBHP as an exogenous agent for creating an oxidative stress model [61], [62], [63].

Oxidative stress is considered to be the major determining factor for the development of diabetes complications, including retinopathy, neuropathy, stroke, and coronary heart disease. It is strongly related to uncontrolled hyperglycemia, which causes the massive exertion of ROS [37], [64], [65], [66]. ROS is a type of free radical associated with oxidative stress, including various chemical compounds with reactive characteristic and are able to act as acceptor or donor electrons (e-) for many biological molecules [65], [67]. Free radicals are chemical molecules containing one or more unpaired electrons that can interfere with the normal signaling process. These free radicals induce cellular damage through their unpaired electrons by triggering the oxidation of the molecule and cellular components. Free radicals have unstable and highly reactive characteristic [65]. Under a physiological normal state, ROS production and its elimination process by endogenous antioxidants is balanced and does not cause any oxidative damage. However, if there are shifts, the imbalance will cause oxidative stress, which triggers cellular injuries [67].

In chronic hyperglycemia, excessive ROS production suppresses both gene expression and insulin secretion as well as triggers pancreatic $\beta$-cells apoptosis, which creates a $\beta$-cells glucose toxicity state [68]. However, a hyperglycemic state will increase the demand for insulin so that the $\beta$-cells become the most metabolically active tissue and are highly dependent on oxidative phosphorylation to generate ATP. High oxygen consumption is required for insulin secretion, whereas $\beta$-cells only have minimal antioxidant enzymes to eliminate superoxide anion $\left(\mathrm{O}_{2}^{-}\right)$. This underlies why $\beta$-cells are susceptible tissues to the risk of higher ROS production and oxidative stress [49], [69]. Collecting in vitro evidence, as mentioned earlier, suggest the potential of S. macrophylla in controlling hyperglycemic conditions through modulation PPAR $\gamma$, GLUT4, and ROS production.

\section{In vivo studies of hypoglycemic properties} of S. macrophylla seeds

The hypoglycemic activity of S. macropylla seeds extract is also supported by numerous in vivo studies. The S. macropylla seeds extract at $300 \mathrm{mg} /$ $\mathrm{kg}$ causes a significant decrease in the blood glucose level in STZ-diabetic rat's model. There was also a decreasing of cholesterol and triglyceride while increasing glycogen contents in the liver [15].

Another evidences demonstrated that alcoholic seeds extract decreases blood glucose, improves body weight, and normalizes serum insulin and liver glycogen content in an STZ-diabetic rat's model [32]. Hashim et al. (2013) performed an intraperitoneal glucose tolerance test (IPGTT) on rats after receiving the petroleum ether (PE) extract of S. macrophylla seeds during 14 days. As a result, a significant enhancement of glucose uptake by abdominal muscle was found, hence reducing blood glucose level [33].

Mursiti (2008) found that 1,4-bis-(3,4,5trimethoxyphenyl)-tetrahydro-furo $(3,4-c)$ furan isolate from $S$. macrophylla seeds, which belongs to saponins class, has the effect of reducing blood glucose in a diabetic rats model [34]. These findings are supported by several further studies. It had a glucoselowering effect and antioxidant activity by reducing malondialdehyde (MDA) levels in a STZ-nicotinamide diabetic rat's model [36]. In addition, the same saponins isolate from $S$. macrophylla was able to suppress blood glucose while increasing pancreatic insulin expression in STZ-induced diabetic rats [29]. These isolates have also been proven to significantly decrease homeostasis model assessment of IR (HOMA-IR), which leads to the improvement of IR in the T2D rats model [35].

HOMA-IR is a method that determines the severity of IR and pancreatic $\beta$-cell function, which is assessed from fasting blood glucose and insulin 
(c-peptide) levels. HOMA-IR is a model that describes the intercourse between glucose and fluctuations in insulin levels. This model predicts fasting blood glucose and insulin levels at various possible combination concentrations of both. Insulin levels are determined by IR and pancreatic $\beta$-cell function and vice versa, insulin determines glucose levels through its role in triggering pancreatic $\beta$-cells to produce glucose. Therefore, pancreatic $\beta$-cell dysfunction will decrease the $\beta$-cell response to glucose concentration to secrete insulin. On the other hand, IR results from the attenuating of insulin-negative feedback in suppressing the production of glucose hepatic (gluconeogenesis). The HOMA-IR model has been accepted as an adequate clinical and epidemiological tool for assessing IR [70]. The use of HOMA-IR in assessing IR has been validated in both children, adolescents, and adults. A value of 2.5 has been determined as the HOMA-IR threshold points for the diagnosis of IR in adults [71].

An in vivo study by Prasetyastuti et al. (2016) showed the hypoglycemic properties of 7-hydroxy2-(4-hydroxy-3-methoxy-phenyl)-chroman-4-one, a flavonoid substance isolated from $S$. macrophylla seeds extract. It reduces blood glucose levels by reducing HOMA-IR and phosphoenolpyruvate carboxykinase (PEPCK) gene expression in T2D rat's model [37]. The PEPCK is an enzyme that crucial in triggering the gluconeogenesis process [72]. Gluconeogenesis is the mechanism of endogenous glucose synthesis from non-carbohydrate substances, including glycerol, amino acids, and lactate, which mainly occur in the liver [73]. PEPCK enzyme triggers the synthesis of phosphoenolpyruvate from oxaloacetate, which is a crucial component in the gluconeogenesis process from mitochondrial substrates [74], [75]. In the postprandial period, insulin inhibits gluconeogenesis by suppressing the expression of PEPCK and glucose 6 phosphatase (G6P). Evidence shows that insulin fails to inhibit the activity of both enzymes in the pre-diabetes state [72].

The 7-hydroxy-2-(4-hydroxy-3-methoxyphenyl)-chroman-4-one isolate also has the ability to improve the $\beta$-cell function by inhibiting the formation of oxidized low-density lipoprotein (ox-LDL) and upregulating the expression of glucagon-like peptide-1 (GLP-1) [38]. The ox-LDL is known for its negative properties on the pancreatic $\beta$-cell since it induces $\beta$-cell apoptosis and inhibits insulin secretion through inducing the C-Jun-N-terminal-kinase (JNK) pathway [76]. GLP-1 is an incretin hormone that has several activities, such as promoting insulin biosynthesis and maintaining $\beta$-cell homeostasis. GLP-1 acts through its receptor (GLP-1R), which is highly expressed in pancreatic $\beta$-cell, to promote insulin secretion in glucose dependent-manner, reduce $\beta$-cell apoptosis, and increase pancreatic $\beta$-cell mass through promoting its proliferation [38], [77], [78], [79]. Hence, GLP-1 is considered as crucial enzyme in determining survival and restoring the function of pancreatic $\beta$-cells [38]. As a response in food ingesting, beyond the intra-pancreatic effects, GLP-1 is also equipped with extra-pancreatic activities, such as triggering glucose uptake, and is responsible for regulating energy homeostasis in rat skeletal muscle and obese individuals via PI3K/Akt and mitogen-activated protein kinase (MAPK) pathways [80]. Regarding its various biological properties, GLP-1 has become an important pharmacological target in the development of a novel therapeutic strategies for the metabolic syndromes including T2D [81], [82].

Therefore, natural compounds capable of increasing GLP-1 expression while reducing PEPCK expression, such as 7-hydroxy-2-(4-hydroxy-3methoxy-phenyl)-chroman-4-one isolated from $S$. macrophylla seeds extract, can be potentially developed as new candidates for T2D, as they are likely to improve IR via restoring pancreatic $\beta$-cell as well as inhibiting gluconeogenesis process.

\section{Molecular mechanisms of hypoglycemic properties from S. macrophylla seeds}

Several molecular mechanisms underlying the hypoglycemic properties of S. macrophylla seeds have been proposed in this review, including modulating the oxidative stress mechanism, restoring the pancreatic $\beta$-cells function through modifying inflammatory pathway and third, through modulation of PI3K/Akt pathway.

\section{Modulating oxidative stress mechanism}

Oxidative stress is an imbalance state between the formation and elimination of ROS [49]. ROS is familiar as the pivotal component in the diabetes pathogenesis and determining factor for the increased risk of diabetes complication [83]. Oxidative stress and ROS trigger IR, impaired insulin synthesis, and insulin secretion [84]. ROS are strongly associated with oxidative stress, and the mitochondrial electron transport chain (ETC) is one of the most important sites for ROS production [67]. Hence, mitochondria are the main source of ROS, since the major of intracellular oxidative stress is derived from the disruption of the mitochondrial respiration process [49], [67], [85]. This indicates that mitochondrial dysfunction is strongly related in promoting $\mathrm{ROS}$ production and oxidative stress condition [86].

Glucose is metabolized in mitochondria through both glycolysis and the tricarboxylic acid cycle to generate ATP with the intermediate products nicotinamide adenine dinucleotide (NADH) and flavin adenine dinucleotide $\left(\mathrm{FADH}_{2}\right)$ [67], [87]. Under hyperglycemia conditions, large amounts of glucose are oxidized, leading to the overproduction of $\mathrm{NADH}$ and $\mathrm{FADH}_{2}$ in the mitochondrial ETC [67]. This causes the increasing of ATP/ADP ratio and promotes the hyperpolarization of mitochondrial membrane potential [86]. The events are followed by excessive 
ROS accumulation, since the elevation of proton gradients promotes the electron transfer to oxygen, which generates superoxide anion $\left(\mathrm{O}_{2}^{-}\right)$[67], [88].

High glucose exposure also triggers mitochondrial morphological changes by inducing mitochondrial fragmentation while inhibiting mitochondrial fusion [89]. Mitochondria are unique organelles with a high degree of plasticity. These organelles often undergo changes in both morphology and intracellular distribution in response to fluctuating metabolic needs. The disturbance in mitochondrial homeostasis causes dysregulation in mitochondrial fragmentation, mitochondrial membrane potential, and apoptosis [90]. The shifting balance toward mitochondrial fission increases the risk of mitochondrial dysfunction, oxidative stress, and apoptosis. Mitochondrial fission is a determining factor for the reduction in ATP generation and the induction of cellular apoptosis, which are influenced by the hyperglycemic condition [90], [91].

Moreover, mitochondrial structural change leads to cellular damage, thereby promoting apoptosis [92]. This process increases the rate of mitochondrial respiration, causing the overproduction of ROS and resulting in oxidative stress on all mitochondrial components [89]. It further alters several signaling pathways and biological processes, including inflammation, DNA damage, and metabolic shift, which are related to T2D pathogenesis and its complication [93].

However, oxygen is crucial in the metabolism of glucose and other substrates to generate ATP in the mitochondria. During the normal oxidative phosphorylation process, up to $0.4-4 \%$ of oxygen will convert into radicals $\mathrm{O}_{2}^{-}$, which are immediately eliminated by antioxidant defense enzymes including superoxide dismutase (SOD), GSH, and catalase (CAT). The SOD enzyme converts $\mathrm{O}_{2}^{-}$into $\mathrm{H}_{2} \mathrm{O}_{2}$ which further detoxified into $\mathrm{H}_{2} \mathrm{O}$ and $\mathrm{O}_{2}$ by $\mathrm{GSH}$ in mitochondria or by CAT in peroxisomes to maintain homeostasis [94].

The overactivity of mitochondrial ETC and massive ROS production in the hyperglycemic state causes an imbalance between pro-oxidant and antioxidant enzymes. This imbalance promotes oxidative stress and cellular damage, especially in the $\beta$-cells, which are only equipped with fewer antioxidant enzymes. Oxidative stress activates JNK and $\mathrm{I}_{\kappa} \mathrm{B}$ kinase $\beta(\mathrm{IKK} \beta)$, which leads to the serine phosphorylation of insulin receptor substrate 1 (IRS1). JNK belongs to the MAPK family, which has a pivotal role in the stress-triggeredcellular response. Its activation is associated with obesity and IR pathogenesis [10], [38], [76], [95]. IKK $\beta$ is the main regulator related to inflammatory response through $N F \kappa \beta$ activation, and has been recognized as related to the cause of IR and T2D [96]. Oxidative stress also induces the secretion of inflammatory molecules from adipose tissues, such as interleukin 6 (IL6) and tumor necrosis factor $\alpha(\mathrm{TNF} \alpha)$, while triggering $\beta$-cell dysfunction [10], [38], [76]. Several cytokines have been known to induce phosphorylation of serine residues on IRS1, such as TNF $\alpha$, IL6, and IL1. This serine phosphorylation suppresses the phosphorylation of tyrosine residues, which are crucial for downstream activation of the insulin signaling pathway, including PI3K and Akt [97]. Beyond decreasing the ability of IRS1 to activate PI3K, the phosphorylation of serine residues also accelerated the degradation of IRS1 [98]. Thus, resulting in the disruption of insulin signaling pathways, which induces IR.

The overproduction of ROS is responsible for the mitochondrial dysfunction associated with diabetes progression [84]. Mitochondria act as the crucial organelle for fatty acids and glucose oxidation. Mitochondrial dysfunction leads to the accumulation of lipid and FFA, followed by the elevation of DAG and ceramide, which interfere with the insulin signaling pathway and are related to the IR. DAG induces the activation of protein kinase $C$ (PKC), hence inhibiting the insulin signaling pathway through inducing of serine/ threonine phosphorylation [8], [99]. Ceramide promotes the activation of phosphoprotein phosphatase $2 \mathrm{~A}$ (PP2A) which responsible for the Akt inactivation. This evidence underlies the plausible interaction between mitochondrial dysfunction, accumulation of FFA, DAG, and ceramide with IR [8].

Figure 2 depicts one of the proposed molecular mechanisms underlying the hypoglycemic activity of $S$. macrophylla seeds through modulation of the oxidative stress pathway related to IR and T2D. S. macrophylla seeds extract showed potent antioxidant activities since it decreased the plasma oxidative stress and induced the release of antioxidant enzymes (SOD, CAT, and GSH) in liver and kidney tissues, hence restoring the oxidant balance in a diabetic rat model [100].

Supporting the hypoglycemic activities of S. macrophylla seeds related to their antioxidant properties, Muthmainah et al. (2019) reported that 1,4-bis-(3,4,5-trimethoxy-phenyl)-tetrahydro-furo(3,4-c) furan from $S$. macrophylla seeds had significant glucose-lowering activity via reducing MDA in a T2D rat model [36]. MDA was known as one of the end products of the lipid peroxidation process related to lipid-oxidative degradation, which causes membrane damage [101]. In this condition, MDA levels can be used as a marker for monitoring the elevation rate of lipid peroxidation induced by excessive $R$ production [67], [102]. Moreover, MDA is a biomarker of oxidative damage in skeletal muscle related to IR [103].

Other systemic markers that commonly increase in metabolic syndrome and are promising for detecting the lipid peroxidation process are thiobarbituric acid-reactive substances (TBARS) and ox-LDL [101]. Interestingly, S. macrophylla alcoholic seeds extract significantly reduces blood glucose in STZ-induced diabetic rats. This hypoglycemic activity was expected related to its antioxidant activities, since it decreased 


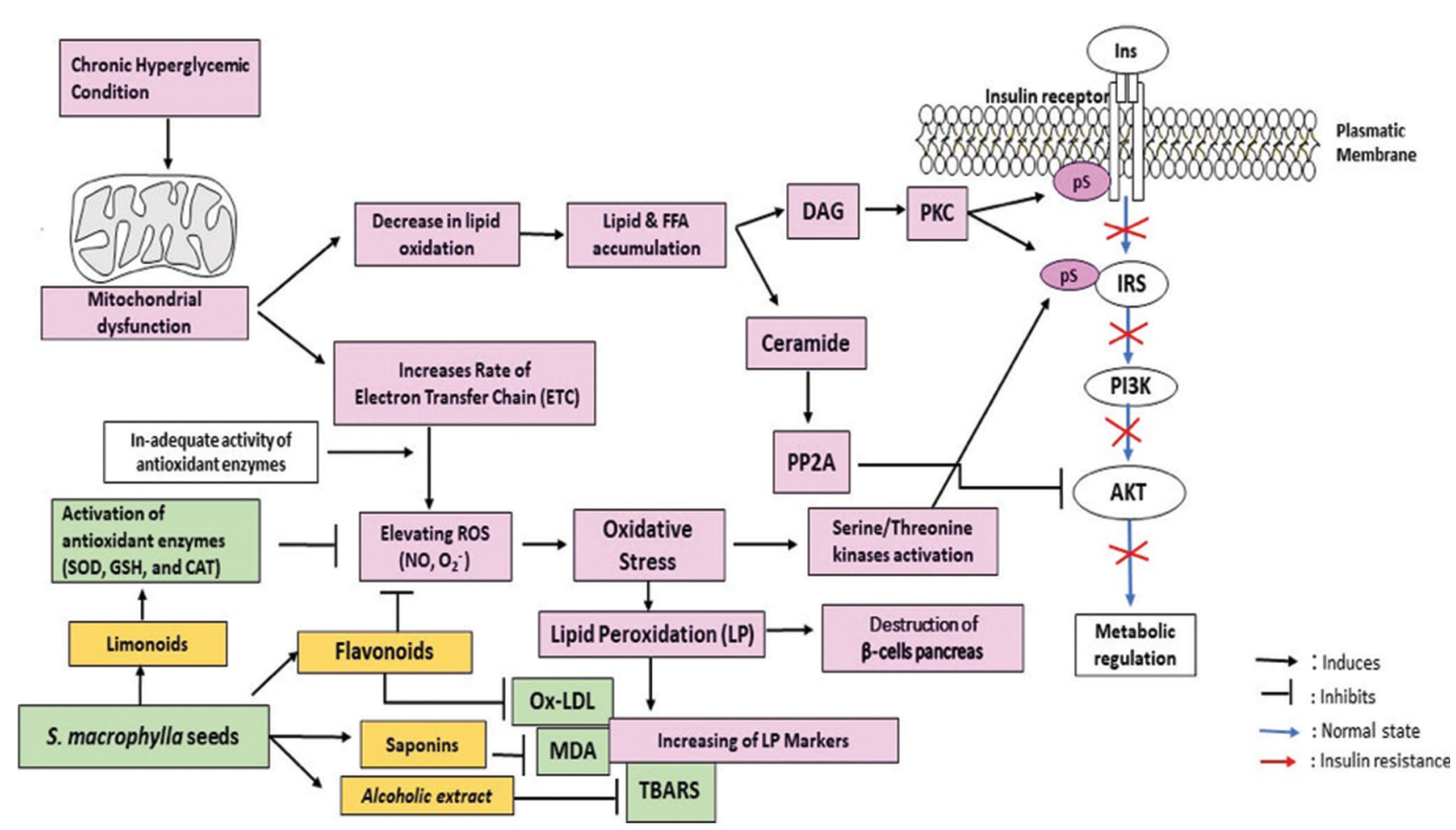

Figure 2: Hypoglycemic molecular activity of Swietenia macrophylla seeds extract through modulating the oxidative stress pathways. Blue arrows indicate the normal state, while red arrows show the insulin signaling pathway in the IR condition. The disruption of insulin signaling initiates by the upregulation of oxidative stress pathways in chronic hyperglycemic condition that promotes the activation of PKC and serine/ threonine kinase, followed by the increases of serine phosphorylation on insulin receptor and IRS1. S. macrophylla seeds contains limonoids, flavonoids, and saponins. Limonoids trigger the activation of antioxidant enzymes that will suppress the excessive production of ROS. Flavonoids inhibit ox-LDL and have activity in inhibiting ROS generation. Saponins reduce MDA marker, while its alcoholic extract inhibits TBARS. The downregulation of ROS and oxidative stress by S. macrophylla seeds will restore insulin signaling pathways and improve IR

the level of TBARS in the plasma, liver, and kidney. Moreover, it increases antioxidant enzymes, including GSH, SOD, and CAT [104]. In agreement with this finding, 7-hydroxy-2-(4-hydroxy-3-methoxy-phenyl)chroman-4-one, a flavonoid isolate from $S$. macrophylla seeds, significantly reduced the ox-LDL level and was expected to restore pancreatic $\beta$-cells function in T2D rats model [38]. This was based on evidence that elevated ox-LDL levels are related to the activation of JNK pathway, which induces the $\beta$-cells apoptosis [76]. These aforementioned findings suggest that several phytoconstituents of $S$. macropylla seeds are able to reduce glucose levels through their effects in modulating oxidative stress related to T2D pathogenesis. It triggers the activity of antioxidant enzymes (SOD, GSH, and CAT), while suppresses ox-LDL and some lipid peroxidation markers (MDA and TBARS).

\section{Modulating the inflammatory pathway related to endoplasmic reticulum (ER) stress}

The ER is a major organelle that crucial for protein maturation and folding, including insulin [93], [105]. ER has been known to be closely related to $I R$ and to the development toward T2D [106], [107]. The ER stress in pancreatic $\beta$-cells and inflammation is a vicious cycle that is interrelated and determines the pathogenesis of diabetes [108]. Therefore, it has become an important target for T2D management [109].

Prolonged exposure to high blood glucose levels in diabetes may trigger ER stress since proinsulin tends to be produced massively in these conditions [110]. This unfolded protein (proinsulin) is overloaded in the ER, resulting in the accumulation of misfolded protein and promoting the ER stress condition [93], [106]. It may generate the unfolded protein response (UPR) pathway for restoring ER homeostasis through its pivotal role in increasing protein folding capacity or reducing misfolded protein accumulation. If this defense mechanism is inadequate, programmed cell death is initiated [107], [108]. As a consequence, $\beta$-cell dysfunction occurs and leads to a decrease in insulin secretion, while promoting $\beta$-cells apoptosis and inflammation in pancreatic islets [93], [108].

Furthermore, in high glucose conditions and a higher demand for insulin secretion, ER stress and oxidative stress are intertwine cycles that work together in accelerating progression toward T2D. Oxidative stress can trigger the accumulation of misfolded protein since it disrupts the balance of ER-redox homeostasis, and conversely, this excessive misfolded protein will induce oxidative stress resulting in apoptosis and $\beta$-cell dysfunction as well as inflammation in 
the pancreatic islets [108], [111], [112]. The whole interconnection further worsens the hyperglycemic state [93], [108], [111].

The accumulation of misfolding proteins is detected by three stress sensor kinases including protein kinase RNA-like endoplasmic reticulum kinase (PERK), inositol-requiring kinase/endoribonuclease 1 (IRE-1), and inducing transcription factor 6 (ATF-6) which lead to the activation of the UPR pathway [8], [105], [112], [113]. Further, these proteins increase chaperones and folding enzymes to enhance protein folding capacities and avoid misfolded protein aggregation [8]. PERK activation reduces global protein synthesis; including the translation of inhibitor $N F \kappa \beta(I \kappa \beta)$ with consequence accelerates the nuclear translocation of nuclear factor kappa $\beta(\mathrm{NF} \kappa \beta)$ [8], [111]. ATF-6 directly activated $N F \kappa \beta$, the nuclear translocation of which induces the genes expression of pro-inflammatory mediators including TNF $\alpha$, IL1, IL6, inducible nitric oxide synthase (iNOS), and cyclooxygenase 2 (COX2). These mediators activate ser kinases, including JNK, IKK $\beta$, and PKC, which triggering the serine phosphorylation of insulin receptor and IRS1. Beyond their interference with IRS1, the pro-inflammatory cytokines also inhibit both the expression and activation of GLUT4 and PPAR $\gamma$. Hence, it will support the development of IR. IRE-1 kinase interconnected with $\mathrm{TNF} \alpha$ receptor-associated factor 2 to activate JNK and IKK $\beta$, which induces the IRS1 serine phosphorylation and disrupts the PI3K/Akt pathway [8], [114]. Moreover, TNF $\alpha$ contributes to IR progression since it increases fat degradation, which causes the elevation of FFA level and down-regulation of GLUT4, with consequences the inhibition of glucose uptake [115].

The ER stress has also been documented to reduce the insulin receptors maturation, hence down regulating the expression of insulin receptors on the cell surface over time. This has implications for the inhibition of Akt insulin-dependent phosphorylation while attenuating the insulin signaling pathway [116]. These events document the strong association between ER stress, inflammation, and IR development [8]. Some evidence indicates that the hypoglycemic molecular mechanism of S. macrophylla seeds involves modulating of the inflammatory pathway-related ER stress in the IR pathogenesis which was known as crucial factor for the development of T2D (Figure 3). The isolate 1,4-bis(3,4,5-trimethoxy-phenil)-tetrahydro-furo(3,4-c)furan from $S$. macrophylla seeds reduced the inflammation process in a T2D rat model by attenuating the activation of $N F \kappa \beta$ and $T N F \alpha$ expression [66]. NF $\kappa \beta$ inhibition by $S$. macrophylla isolates is expected to suppress the translation of pro-inflammatory cytokines, thereby reducing the level of inflammation and ER stress triggered by hyperglycemia. In addition, the ability of S. macrophylla isolates in inhibiting $\mathrm{TNF} \alpha$ is expected to improve IR. This is based on the evidence that increasing levels of serum TNF $\alpha$ positively correlated with IR pathogenesis since it triggers JNK pathway and serine phosphorylation on IRS1, while inhibiting GLUT4. It results in the impairment of PI3K/Akt insulin signaling pathway [8], [114], [117].

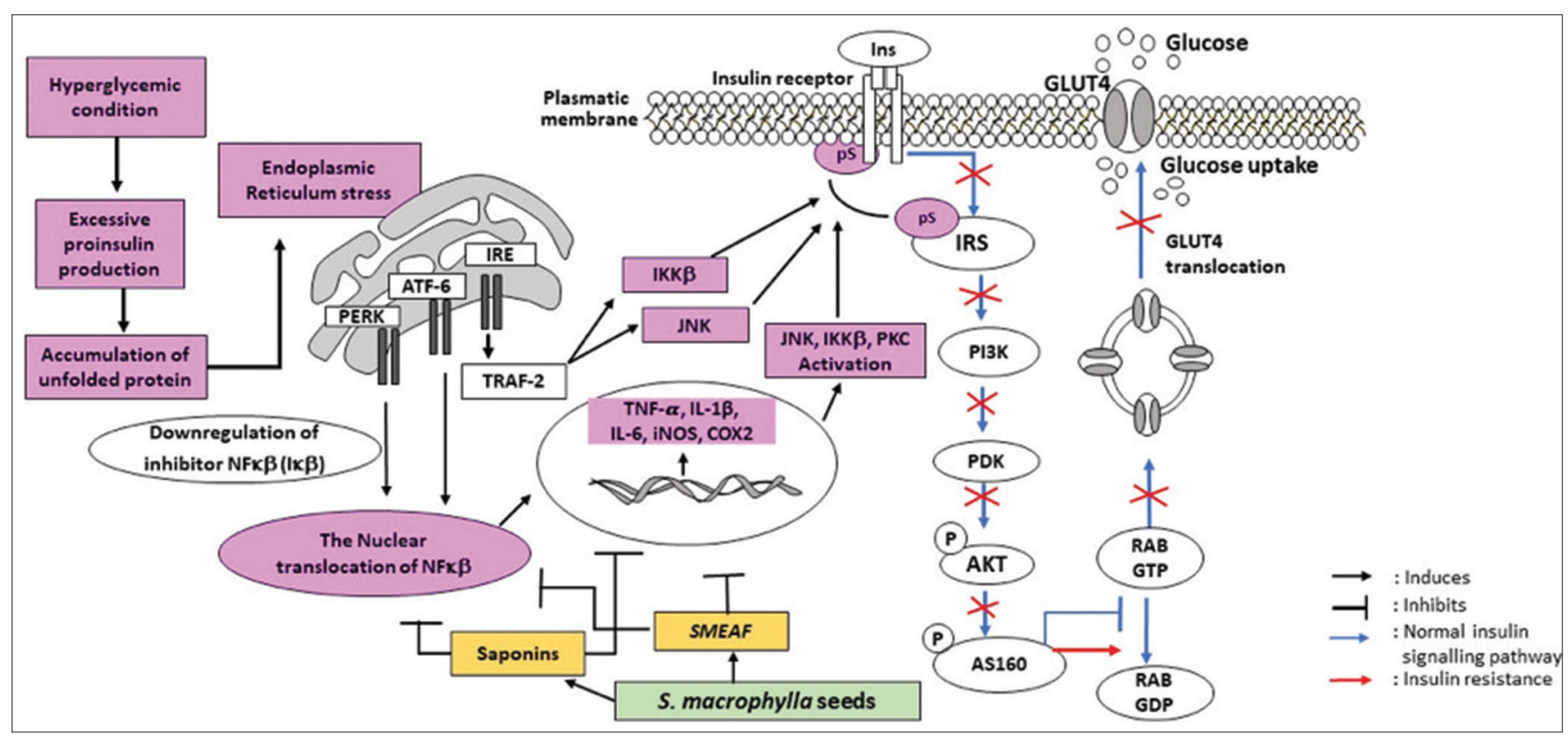

Figure 3: Hypoglycemic molecular activity of Swietenia macrophylla seeds extract via modulating the inflammatory pathways related to ER stress. Blue arrows indicate the normal state, while red arrows show the insulin signaling pathway in the IR condition. The disruption of insulin signaling initiates by the accumulation of unfolded protein due to excessive proinsulin production in hyperglycemic condition. It causes ER stress and triggers the stress sensor kinases (PERK, ATF-6, and IRE) which promote the unfolded protein response (UPR). The UPR will promote the $N F \kappa \beta$ nuclear translocation followed by the upregulation of pro-inflammatory mediators. The UPR also promotes the activation of JNK, IKK $\beta$ and PCK which were followed by the increases of serine phosphorylation on insulin receptor and IRS1. Saponins and ethyl acetate

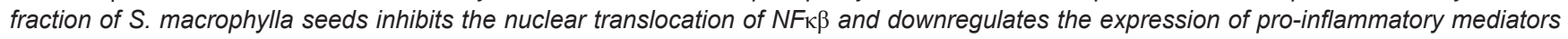
(TNF- $\alpha$, iNOS and COX2). All of those mechanisms will decrease serine phosphorylation on insulin receptors and IRS1, hence restoring the insulin signaling pathways and improving IR 
Another evidences showed the ethyl acetate fraction of $S$. macrophylla excreted anti-inflammatory effect in lipopolysaccharide (LPS)-induced BV-2 microglia through inhibition of IK $\beta$ phosphorylation and $N F \kappa \beta$ nuclear translocation. It leads to the downregulation of pro-inflammatory cytokines expression, including $\mathrm{TNF} \alpha$ and IL6. It also suppresses the expression of inflammatory mediators, such as iNOS and COX2 [118].

The iNOS upregulation has been found in many pathologic conditions, such as hyperglycemic, oxidative stress, and elevated FFA, while its inhibition has been proven to induce the expression of IRS1 and IRS2 in the obese diabetic mice model [119]. iNOS generates excessive NO metabolite, which alters tyrosine phosphorylation and further interferes with the insulin signaling pathway associated with IR [120]. Hence, suppressing iNOS can be a plausible mechanism in improving insulin sensitivity and potentially has a beneficial effect in controlling blood glucose in obese diabetic patients [119]. COX2 is known for its effect on the inflammation process and IR [121]. It is responsible for prostaglandin synthesis, which mediates COX2 effects on T2D pathogenesis and its complications [122]. The elevation of COX2 levels in the chronic inflammatory state worsens this condition [121]. In hyperglycemic conditions, both iNOS and COX2, are contributing in inducing endothelial apoptosis and are responsible for the progression of diabetic complication [123].

As phytochemical agents for preventing the progression of $I R$ and T2D, the extracts of $S$. macrophylla seeds seem to play a role in modulating the inflammatory state related to ER stress (inhibit $N F \kappa \beta, T N F \alpha$, iNOS, and COX2) as one of the plausible pathogenesis of IR and T2D.

\section{Modulating PI3K/Akt pathway}

The PI3K/Akt signaling pathway is responsible for many cellular mechanisms in the body, including glucose homeostasis, lipid metabolism, protein synthesis, cell proliferation, and survival [124]. Glucose homeostasis is the mechanism to maintain a normal blood glucose level between $70-100 \mathrm{mg} / \mathrm{dl}$. This is regulated tightly by maintaining the balance between the process that produces glucose (diet containing glucose, glycogenolysis, and gluconeogenesis) and the process of consuming blood glucose (glycolysis, glycogenesis, and lipogenesis) [84]. The inhibition of the PI3K-Akt insulin signaling pathway results in decreased sensitivity of the target cells to insulin. This condition promotes pancreatic $\beta$-cells to produce insulin continuously as compensation for reducing blood glucose. This compensation triggers hyperinsulinemia and increases the workload of $\beta$-cells. This, in turn, leads to hyperproliferation and apoptosis induction of $\beta$-cells, followed by IR and even T2D [125].

The PI3K/Akt pathway is initiated by insulin binding to its receptor subunit $\alpha$, followed by autophosphorylation and activation of the insulin receptor subunit $\beta$. This results in tyrosine phosphorylation and the activation of downstream molecular signals, including IRS, PI3K, and Akt [126]. The Akt activation could improve IR through several mechanisms, such as facilitating the glucose uptake induced by GLUT4 translocation, increasing glycogen synthesis through downregulation of glycogen synthase kinase $3 \beta(G S K-3 \beta)$, and suppress gluconeogenesis by triggering the Forkhead box protein class $\mathrm{O}$ type 1 (FOXO1) phosphorylation that will inhibit PEPCK gene expression [8], [124], [127], [128]. The phosphorylation of FOXO1 by activated Akt will inhibits the intranuclear signaling of FOXO1 and suppresses gluconeogenesis [129]. The FOXO1 actively contributes to the development of IR by inducing the transcription of various transcription factors that determine glucose and lipid metabolisms as well as the adipogenesis processes. This promotes gluconeogenesis, thereby elevating blood glucose levels and also induces hyperinsulinemia as it consequent [130].

The induction of GLUT4 translocation in skeletal muscle by Akt is associated with AS160, which is known as one of Akt substrates. AS160 is the RabGTPase activating protein (GAP) that crucial for vesicle trafficking process. In basal conditions, AS160 acts as GAP, which stabilizes GLUT4 in their vesicles, whereas in the active Akt form, insulin stimulation leads to the phosphorylation of AS160. It causes the deactivation of its function as GAP, hence inducing GLUT4 translocation and glucose entry into skeletal muscle [127], [131].

The PI3K/Akt pathway is known as one of the mediators for glucose homeostasis and glycogen synthesis. Hence, the disruption of this pathway plays a crucial role in the pathogenesis of T2D [124]. The impaired phosphorylation of the insulin signaling pathway in skeletal muscle and adipose tissues leads to the downregulation of GLUT4 expression and its translocation thus decreased glucose uptake. The IR also induced gluconeogenesis, while inhibiting glycogen synthesis in the liver [132], [133].

The hypoglycemic properties of S. macrophylla seeds and its effects on improving the IR might also be through modulating PI3K/Akt pathway (Figure 4). The 6-O-acetylswietenolide, diacetyl swietenolide, and swietenine from S. macrophylla seeds induced GLUT4 membrane translocation in $\mathrm{C} 2 \mathrm{C} 12$ muscle cell line [26]. The GLUT4 is the main transporter that plays a role in glucose homeostasis, which was $60-70 \%$ in skeletal muscles. Its translocation leads to glucose uptake on insulin-sensitive tissues [124], [127]. The failure of GLUT4 membrane translocation due to the reducing response to insulin stimulation leads to the development of IR and T2D [134]. Moreover, 7-hydroxy-2-(4-hydroxy3-methoxy-phenyl)-chroman-4-one, flavonoids from $S$. macrophylla seeds extract was able to modulate the downstream of PI3K/Akt pathway, demonstrated by its ability to downregulate PEPCK expression in a T2D rat model [37]. 


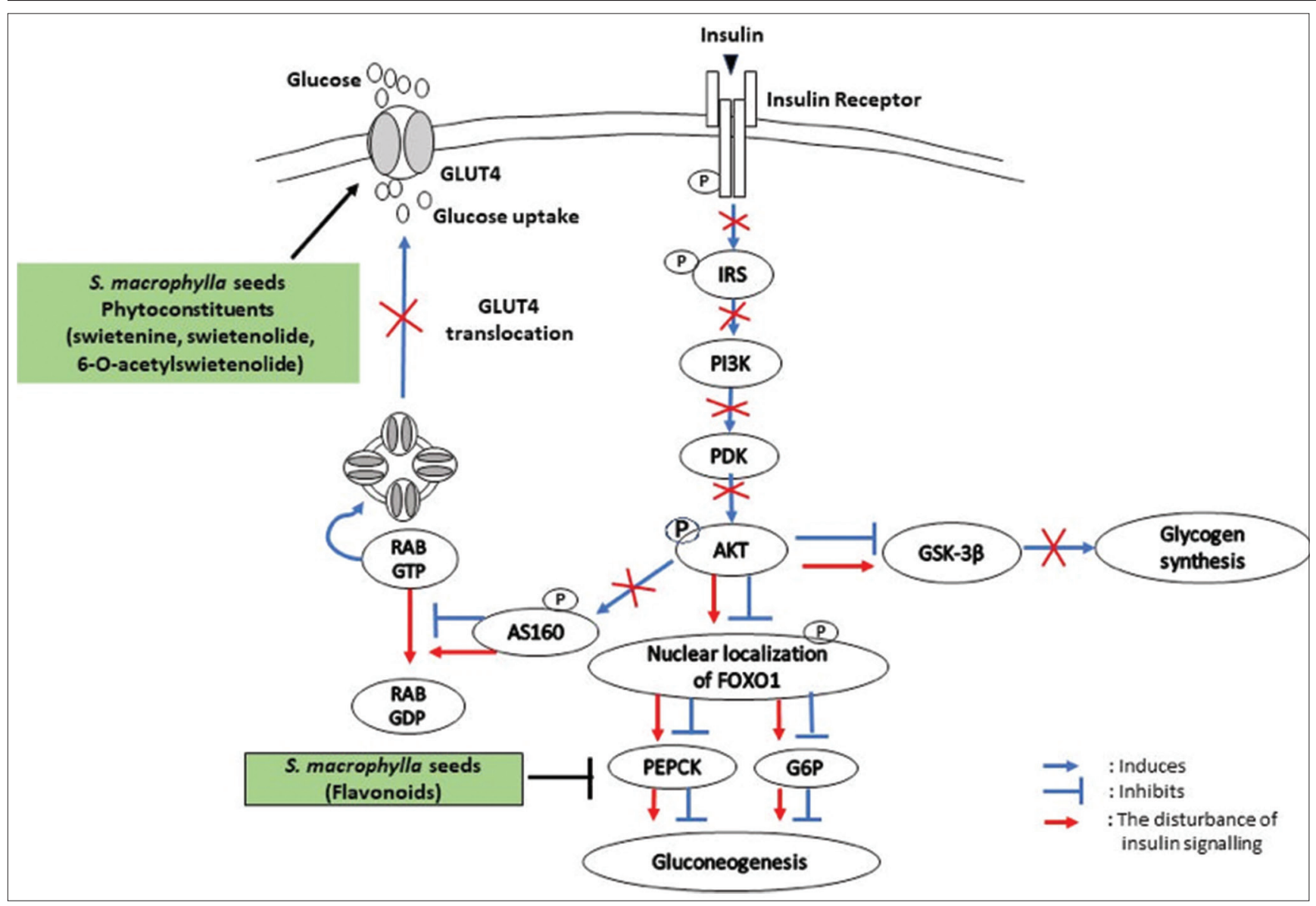

Figure 4: Hypoglycemic molecular activity of Swietenia macrophylla seeds extract via modulating the PI3K/Akt pathway. Blue arrows indicate the normal IRS1-PI3K-Akt-GLUT4 insulin signaling pathway, while red arrows indicate the disturbance of insulin signaling pathway in IR condition. Phytoconstituents from S. macrophylla seeds extract promote the GLUT4 membrane translocation followed by the increasing rate of glucose uptake, while its flavonoids inhibit PEPCK and suppresses the gluconeogenesis

Several phytochemicals from S. macrophylla seeds have been shown to modulate the PI3K/Akt pathway. This is promising because PI3K/Akt is an important pathway for glucose regulation in insulinsensitive tissues, such as muscle, liver, and adipose tissue. This phytochemical from S. macrophylla not only promotes glucose uptake in the muscle through GLUT4 induction but also suppresses hepatic glucose synthesis (gluconeogenesis) through the inhibition of PEPCK.

\section{Phytochemical compounds of S. macrophylla seeds responsible for hypoglycemic effects}

The hypoglycemic effect of $S$. macrophylla seeds seems mediated by components such as limonoids, flavonoids, and saponins. Limonoids from S. macrophylla seeds have anti-inflammatory activity by suppressing the $\mathrm{O}_{2}{ }^{-}$generation in an inflammatory model using human neutrophils fMLP-induced $\mathrm{O}_{2}$. Moreover, limonoids have also been shown to be potent inhibitors against LPS-induced NO generation [135]. In line with this, (Supriady et al. 2015) showed that a high amount of limonoids in SMEAF $(17.34 \%)$ might related to the inhibition effect of SMEAF on the generation of pro-inflammatory mediators, including NO, COX2, TNF $\alpha$, and IL6 [118].

The $\mathrm{O}_{2}^{-}$is one of the oxygen-free radicals with a highly reactive capacity [49], while NO is a gas and categorized as a free-radical produced by the endothelium. The disturbance in NO bioavailability is associated with various diseases, including diabetes and its complications [136]. NO at a physiological level has a beneficial effect in triggering endogenous antioxidant activity, whereas at excessive levels, it turns into a pro-oxidant and become highly reactive, especially with $\mathrm{O}_{2}^{-}$[137]. High amounts of $\mathrm{O}_{2}^{-}$will immediately react with NO to generate peroxynitrite radicals (ONOO-), which result in membrane lipid peroxidation, interfere with cellular signaling processes, and act as pro-inflammatory mediator [136], [137].

Our hypothesis that limonoids are one of the suspected phytochemicals underlying the antiinflammatory effect of $S$. macrophylla related to its hypoglycemic activity is supported by evidence that limonoids from other plants are able to act as antiinflammatory agents. Several limonoids isolated from Cortex Dictamni, Chinese herbs commonly used for inflammation and rheumatic pain, have been proven to act as anti-inflammatory compounds by suppressing 
the production of NO, iNOS, COX2, NFK $\beta, \mathrm{TNF} \alpha$, and IL6 in the inflammatory model using cell line RAW 264.7 induced by LPS [138]. Limonoids from Swietenia humilis have been shown to suppress the glycemic index during an oral glucose tolerance test in a hyperglycemic mice model induced by STZ-NA. These limonoids possess moderate activities in inhibiting the harmful effect caused by free radicals [139].

Other phytochemicals responsible for the hypoglycemic effect of $S$. macropylla seeds are flavonoids. The 7-hydroxy-2-(4-hydroxy-3-methoxyphenyl)-chroman-4-one flavonoids compounds from S. macrophylla seeds possess hypoglycemic activities related to anti-oxidative mechanisms that may be due to its hydroxyl group, which inactivates radical reactive compounds and stabilizes ROS [38]. The B ring hydroxyl configuration of flavonoids has been reported to have strong radical scavenging activity through its role as hydrogen and electron donors to hydroxyl, hydroperoxyl, and peroxynitrite radicals, thereby stabilizing these ROS. Notably, the total number of hydroxyl groups in flavonoids isolated from Tetracera indica Merr. and Tetracera scandens (L.) Merr. has been shown to play a major role in determining its activity as an antioxidant and antidiabetic [140].

Flavonoids as polyphenol secondary bioactive compounds have been reported to possess natural therapeutic activities that target inflammation related to diabetes pathogenesis [141]. Natural flavonoids have been shown to have potential antidiabetic activity from several studies. The antidiabetic activity of these flavonoids is mediated by their role in modulating pancreatic $\beta$ cells (protective effect on $\beta$ cells from damage, promoting $\beta$ cell proliferation, and improving insulin signaling, thereby increasing insulin secretion). Flavonoids also increase glucose utilization by inducing glucose transporters and insulin signaling pathways, while reducing intestinal glucose absorption through inhibition of alpha-glucosidase enzyme. In addition, flavonoids are able to inhibit glycogenolysis and gluconeogenesis by increasing levels of glucokinase enzymes and inhibiting PEPCK gene expression [142].

Flavanol-rich green tea extract is able to promote several genes expression involved in the insulin pathway, such as IRS1 and GLUT4, in the skeletal muscle tissues of mouse models induced by high-fat diet. Epigallocatechin gallate, the main flavonoids content in green tea, has also been shown to suppress hepatic glucose production by promoting Akt to decrease fasting blood glucose and insulin levels in mice [133]. Genistein, a flavonoid from legumes administered to STZ-induced diabetic mice, was reported to have a protective effect, increasing the proliferation and survival rate of pancreatic $\beta$ cells [143]. Flavonoid-rich extract from the flower of Wisteria sinensis has been shown to have potential effects in attenuating T2D both in vitro and in vivo using cell line L6 (rat skeletal muscle) and T2D mice model induced by high fat diet and STZ. The antidiabetic mechanism of these flavonoids is through their role in modulating the IRS1/PI3K/Akt/GLUT4 signaling pathway [144].

Apart from limonoids and flavonoids, saponins are also considered to play a major role in mediating the hypoglycemic effect of $S$. macrophylla. The saponins 1,4-bis-(3,4,5-trimethoxy-phenyl)-tetrahydrofuro(3,4-c)furan from $S$. macrophylla seeds, possesses hypoglycemic effects related to antioxidative and anti-inflammatory mechanisms through their role in modulating MDA and TNF $\alpha$ level [37], [118]. Supporting this finding, saponins from Momordica charantia showed potential antidiabetic effects in a T2D rat model induced by a high fat diet-STZ through suppressing stress oxidative pathways (inducing the activities of SOD and CAT enzymes while decreasing MDA levels in the liver and pancreas), modulating insulin signaling pathways (promoting the tyrosine phosphorylation of IRS-1 and Akt Ser-473 while reducing the serine phosphorylation of IRS-1), and attenuating metabolic markers (reducing non-esterified fatty acid, triglyceride, and total cholesterol) [145]. In vitro studies have shown steroidal saponins and sapogenins from fenugreek potential as hypoglycemic agents through their role in promoting the $\alpha$-glucosidase enzyme [146]. Saponins from Stauntonia chinensis was reported to exert hypoglycemic activity by lowering blood glucose, improving insulin response, and increasing glycogen synthesis through induction of GLUT4 involved in the activation of the IRS1/PI3K/ Akt signaling pathway in $\mathrm{dB} / \mathrm{dB}$ mice. In addition, these saponins attenuate hyperlipidemia associated with $\mathrm{T} 2 \mathrm{D}$ pathogenesis [147].

These findings altogether propose that the glucose-lowering effects of saponins occur through several mechanisms, that is, the improvement of insulin response and insulin signaling process, increase in insulin secretion, induction of glycogen synthesis, inhibition of gluconeogenesis and $\alpha$-glucosidase activity, upregulation of GLUT4 expression, and downregulation glycogen phosphorylase expression [148]. The $-\mathrm{OH}$ groups in the saponins structure play a role in enhancing its ability as an antioxidant since it has the ability to improve the production of antioxidant enzymes, including SOD and CAT [148], [149]. Hence, it may prevent the formation of ROS associated with diabetes pathogenesis. Overall, the evidence described above supports that the limonoids, flavonoids, and saponins contained in $S$. macrophylla seeds play a pivotal role in its hypoglycemic effect.

\section{Safety profile of S. macrophylla seeds} extract

The potency of this compound is also supported by its safety profile through both in vitro cytotoxicity and in vivo toxicity tests. 


\section{In vitro cytotoxicity test of S. macrophylla seeds extract}

The inhibitory concentration $50 \quad\left(I C_{50}\right)$ is described as the concentration of a compound that causes $50 \%$ inhibition of sample cells compared to the untreated-control group. The $\mathrm{IC}_{50}$ value represents the compound's inhibition potency [150]. All three compounds (6-O-acetylswietenolide, diacetyl swietenolids, and swietenine) from $S$. macrophylla seeds did not possess any cytotoxicity effect since the $\mathrm{IC}_{50}$ values on $\mathrm{C} 2 \mathrm{C} 12$ and 3T3-L1 cell lines were higher than $100 \mu \mathrm{M}$ [26]. A Vero cell cytotoxicity test showed that 1,4-bis-(3,4,5-trimethoxy-phenyl)-tetrahydrofuro(3,4-c)furan from $S$. macrophylla seeds was not toxic, as the $\mathrm{IC}_{50}$ was more than $260 \mu \mathrm{g} / \mathrm{ml}$ [151].

\section{In vivo toxicity test of S. macrophylla seeds extract}

During the drug discovery and development process of a new candidate agent, in vivo toxicity testing is needed to evaluate the potential adverse effect and safety margin of this candidate for human consumption. Moreover, this toxicity test acts as a preclinical study to examine any toxicity sign in an animal model for estimating its relevance risk in human [152].

Balijepalli et al. (2015) conducted acute oral toxicity test of S. macrophylla seeds. The raw powder of $S$. macrophylla seeds without any extraction was given orally to Sprague Dawley rats to create similarities according to the way its compound was consumed by humans. This study demonstrated that $2000 \mathrm{mg} / \mathrm{kg}$ BW body weight of S. macrophylla seeds powder as a single dose did not alter the behavioral pattern of rats, the food and water consumption habits, the vital organ weight and its histological structures, or the hematological and biochemical parameters. Furthermore, no toxicity signs or mortality were observed during the study period. These results provided evidence that $2000 \mathrm{mg} / \mathrm{kg}$ BW of raw $S$. macrophylla seeds was not toxic, and its consumption as a folklore remedy is relatively safe. In human, the safe dose of $S$. macrophylla seeds is less than $325 \mathrm{mg} /$ $\mathrm{kg} \mathrm{BW}$, which is equivalent to a dose of $2000 \mathrm{mg} / \mathrm{kg}$ $\mathrm{BW}$ in rats [153].

The acute toxicity evaluation of the ethyl acetate fraction of $S$. macrophylla seeds based on the OECD 425 guidelines showed that SMEAF at a dose of $2000 \mathrm{mg} / \mathrm{kg} \mathrm{BW}$ did not cause any mortality in the animals that were used in this study. Hence, its LD50 value was more than 2000 mg/kg BW. Moreover, there were no clinical symptoms, abnormal behavioral patterns, or toxic signs in the mice at $4 \mathrm{~h}, 24 \mathrm{~h}$, or up to 14 days during the observation. The ethyl acetate fraction also tended to have no adverse effect on the hematological parameters, bodyweight, or intake of food and water in both the control and treated group.
Histological structure of the liver, spleen, and kidneys of animals in this study remained normal without any inflammatory signs, necrosis, or fibrosis. Therefore, this finding indicates that the traditional consumption of S. macrophylla seeds is relatively safe and practically non-toxic [31].

Sahgal et al. (2010) observed the acute oral toxicity of the methanolic extract from Swietenia mahogany (Linn.) Jacq on brine shrimp. $S$. mahagony Jacq. is in the same genus "Swietenia" as S. macrophylla [25]. The results indicated that the oral $L D_{50}$ value of the methanolic extract of $S$. mahagony Jacq was more than $5000 \mathrm{mg} / \mathrm{kg} \mathrm{BW}$. It was interpreted this extract as a safe compound. The methanolic extract of S. mahogany (Linn.) Jacq also did not alter the histological structure of important organs, such as the heart, liver, kidney, lung, and spleen [154].

Both the in vitro and in vivo toxicity tests documented above have proven that S. macrophylla seeds are safe and not toxic. This supports its further development as a natural product for diabetes management.

\section{Conclusion}

This review offers a comprehensive understanding of the molecular mechanisms underlying the hypoglycemic properties of $S$. macrophylla seeds, which occur through modulating several pathways known to be associated with the pathogenesis of $\mathrm{IR}$ and $\mathrm{T} 2 \mathrm{D}$, including oxidative stress, inflammation related to ER stress, and activation of PI3K/Akt pathways. This review also provides evidence related to the safety profile of $S$. macrophylla seeds. Therefore, these phytochemicals can potentially be developed as antidiabetic agents. However, further studies of the pharmacokinetic profile of S. macrophylla and extensive clinical trials are needed to establish its use as an antidiabetic agent in clinical settings.

\section{Authors Contribution}

All authors have contributed significantly and have approved the manuscript submission. RDY contributed in designing, data collecting, and drafting the manuscript. DAAN and $\mathrm{M}$ gave the concept and critically revised the manuscript, whilst ENS contributed in giving the general structure of manuscript and obtaining the funding. 


\section{Acknowledgments}

The authors would like to express our appreciation to Mr. Arko Ario Wicaksono for his assistance. This project was supported by the Indonesian Ministry of Research, Technology and Higher Education under PDUPT Grant 2020 (6/AMD/ E1/KPT.PTNBH/2020 and 2755/UN1.DITLIT.DIT-LIT/ PT/2020 and 2755/UN1.DITLIT.DIT-LIT/PT/2020).

\section{References}

1. Cho NH, Shaw JE, Karuranga $S$, Huang $Y$, da Rocha Fernandes JD, Ohlrogge AW, et al. IDF Diabetes Atlas: Global estimates of diabetes prevalence for 2017 and projections for 2045. Diabetes Res Clin Pract. 2018;138:271-81. https://doi. org/10.1016/j.diabres.2018.02.023

PMid:29496507

2. International Diabetes Federation. IDF Diabetes Atlas. $8^{\text {th }}$ ed. Brussels, Belgium: International Diabetes Federation; 2017. p. 1-150. https://doi.org/10.1016/j.diabres.2015.05.037

3. Wu Y, Ding Y, Tanaka Y, Zhang W. Risk factors contributing to Type 2 diabetes and recent advances in the treatment and prevention. Int J Med Sci. 2014;11(11):1185-200. https://doi. org/10.7150/ijms.10001

PMid:25249787

4. Zheng Y, Ley SH, Hu FB. Global aetiology and epidemiology of Type 2 diabetes mellitus and its complications. Nat Rev Endocrinol. 2018;14(2):88-98. https://doi.org/10.1038/ nrendo.2017.151

PMid:29219149

5. Ashcroft FM, Rorsman P. Diabetes mellitus and the $\beta$ cell: The last ten years. Cell. 2012;148(6):1160-71. https://doi. org/10.1016/j.cell.2012.02.010

PMid:22424227

6. Ozougwu J, Obimba K, Belonwu C, Unakalamba C. The pathogenesis and pathophysiology of Type 1 and Type 2 diabetes mellitus. J Physiol Pathophysiol. 2013;4(4):46-57. https://doi.org/10.5897/jpap2013.0001

7. Lee BC, Lee J. Cellular and molecular players in adipose tissue inflammation in the development of obesity-induced insulin resistance. Biochim Biophys Acta. 2014;1842(3):446-62. https:// doi.org/10.1016/j.bbadis.2013.05.017

PMid:23707515

8. Rodelo CG, Guiberna AR, Reyes JA. Cellular mechanisms of insulin action. Gac Med Mex. 2017;153:197-209.

9. Alsadat S, Khorami H. PI3K/AKT pathway in modulating glucose homeostasis and its alteration in diabetes. Ann Med Biomed Sci. 2015;1(2):46-55.

10. Samuel VT, Shulman GI. The pathogenesis of insulin resistance: Integrating signaling pathways and substrate flux. J Clin Invest. 2016;126(1):12-22. https://doi.org/10.1172/jci77812 PMid:26727229

11. Tahrani AA. Novel therapies in Type 2 diabetes: Insulin resistance. Pract Diabetes. 2017;34(5):161-6a. https://doi. org/10.1002/pdi.2109

12. Nolan CJ, Prentki M. Insulin resistance and insulin hypersecretion in the metabolic syndrome and Type 2 diabetes: Time for a conceptual framework shift. Diabetes Vasc Dis Res.
2019;16(2):118-27. https://doi.org/10.1177/1479164119827611 PMid:30770030

13. Tahrani AA, Bailey CJ, Del Prato S, Barnett AH. Management of Type 2 diabetes: New and future developments in treatment. Lancet. 2011;378(9786):182-97. https://doi.org/10.1016/ s0140-6736(11)60207-9

PMid:21705062

14. Hung HY, Qian K, Morris-Natschke SL, Hsu CS, Lee KH Recent discovery of plant-derived anti-diabetic natural products. Nat Prod Rep. 2012;29(5):580-606. https://doi.org/10.1039/ c2np00074a PMid:22491825

15. Maiti A, Dewanjee S, Kundu M, Mandal SC. Evaluation of antidiabetic activity of the seeds of Swietenia macrophylla in diabetic rats. Pharm Biol. 2009;47(2):132-6. https://doi. org/10.1080/13880200802436703

16. Kamgang R, Youmbi Mboumi R, Foyet Fondjo A, Fokam Tagne MA, Mengue N'dillé GP, Ngogang Yonkeu J. Antihyperglycaemic potential of the water-ethanol extract of Kalanchoe crenata (Crassulaceae). J Nat Med. 2008;62(1):3440. https://doi.org/10.1007/s11418-007-0179-y

PMid:18404339

17. Prabhakar PK, Doble M. Mechanism of action of natural products used in the treatment of diabetes mellitus. Chin J Integr Med. 2011;17(8):563-74. https://doi.org/10.1007/s11655-011-0810-3 PMid:21826590

18. Moghadamtousi SZ, Goh BH, Chan CK, Shabab T, Kadir HA Biological activities and phytochemicals of Swietenia macrophylla king. Molecules. 2013;18(9):10465-83. https://doi. org/10.3390/molecules180910465 PMid:23999722

19. Maiti A, Dewanjee S, Jana G, Mandal S. Hypoglycemic effect of Swietenia macrophylla seeds against Type II diabetes. Int J Green Pharm. 2008;2(4):224-7. https://doi. org/10.4103/0973-8258.44738

20. Dewanjee S, Maiti A, Das AK, Mandal SC, Dey SP. Swietenine: A potential oral hypoglycemic from Swietenia macrophylla seed. Fitoterapia. 2009;80:249-51. https://doi.org/10.1016/j. fitote.2009.02.004

PMid:19239921

21. Dutta M, Biswas $U$, Chakraborty R, Banerjee P, Raychaudhuri U. Regeneration of pancreatic $\beta$-cells on streptozotocin induced diabetic rats under the effect of Swietenia macrophylla seeds. Int J Green Pharm. 2012;6(4):336-9. https://doi. org/10.4103/0973-8258.108253

22. Eid AM, Elmarzugi NA, El-Enshasy HA. A review on the phytopharmacological effect of Swietenia macrophylla. Int J Pharm Pharm Sci. 2013;5(3):47-53.

23. Maiti A, Dewanjee S, Mandal SC, Annadurai S. Exploration of antimicrobial potential of methanol and water extract of seeds of Swietenia macrophylla (Family: Meliaceae), to substantiate folklore claim. Iran J Pharmacol Ther. 2007;6(1):99-102.

24. Patel DK, Prasad SK, Kumar R, Hemalatha S. An overview on antidiabetic medicinal plants having insulin mimetic property. Asian Pac J Trop Biomed. 2012;2(4):320-30. https://doi. org/10.1016/s2221-1691(12)60032-x PMid:23569923

25. Naveen YP, Rupini DG, Ahmed F, Urooj A. Pharmacological effects and active phytoconstituents of Swietenia mahagoni: A review. J Integr Med. 2014;12(2):86-93. https://doi. org/10.1016/s2095-4964(14)60018-2 PMid:24666674

26. Lau WK, Goh BH, Kadir HA, Shu-Chien AC, Muhammad TS, McPhee DJ. Potent PPAR ligands from Swietenia macrophylla are capable of stimulating glucose uptake in muscle cells. 
Molecules. 2015;20(12):22301-14. https://doi.org/10.3390/ molecules201219847

PMid:26703529

27. Arumugasamy K, Latha K, Kumar N. Studies on Some Pharmacognostic Profiles of Swietenia Macrophylla. King. Anc Sci Life. 2004;24(2):97-102.

PMid:22557161

28. Durai MV, Balamuniappan G, Geetha S. Phytochemical screening and antimicrobial activity of leaf, seed and centralfruit-axis crude extract of Swietenia macrophylla King. J Pharmacogn Phytochem. 2016;5(3):181-6.

29. Nugraha A. Molecular Docking and Antihyperglycemic Activity of Active Compounds Which Isolated from Methanol Extract of Swietenia macrophylla King Seeds in Diabetic Rats Induced by Streptozotocin (Translate from Indonesia Language). Yogyakarta: Universitas Gadjah Mada; 2012.

30. Vigneshwaran LV, Lalitha KG. In silico evaluation of antidiabetic molecules of the seeds of Swietenia mahagoni Jacq. Int J Pharm Phytopharm Res. 2017;6(1):41-9. https://doi.org/10.24896/ eijppr.2016617

31. Sayyad M, Tiang N, Kumari Y, Goh BH, Jaiswal Y, Rosli R, et al. Acute toxicity profiling of the ethyl acetate fraction of Swietenia macrophylla seeds and in-vitro neuroprotection studies. Saudi Pharm J. 2017;25(2):196-205. https://doi.org/10.1016/j. jsps.2016.05.002

32. Kalaivanan K, Pugalendi KV. Antihyperglycemic effect of the alcoholic seed extract of Swietenia macrophylla on streptozotocin-diabetic rats. Pharmacogn Res. 2011;3(1):67-71. https://doi.org/10.4103/0974-8490.79119 PMid:21731399

33. Hashim MA, Yam MF, Hor SY, Lim CP, Asmawi MZ, Sadikun A. Anti-hyperglycaemic activity of Swietenia macrophylla king (meliaceae) seed extracts in normoglycaemic rats undergoing glucose tolerance tests. Chin Med. 2013;8(1):1-8. https://doi. org/10.1186/1749-8546-8-11

PMid:23684219

34. Mursiti S. Isolation Compound Antidiabetes Mellitus from the Seeds of Mahogany (Swietenia macrophylla King) (Translate from Indonesia Language) Doctoral's Desertation. Yogyakarta: Universitas Gadjah Mada; 2008. Available from: http://www.etd.repository.ugm.ac.id/penelitian/detail/88637. [Last assessed on 2021 Jan 31].

35. Yusuf M. The Effects of 1,4-bis-(3,4,5-trimetoxy-fenyl)tetrahydrofuro (3,4-c) Furan Isolate on Insulin Resistance and Expression of IRS-1 Serine 307 Protein in Skeletal Tissues of DM Type 2 Rats Model (Translate from Indonesia Language). Indonesia: Universitas Gadjah Mada; 2016.

36. Muthmainah M, Yarso KY, Purwanto B, Mudigdo A, Mustofa M. 1,4-bis-3,4,5-trimethoxy-phenyl-tetrahydro-furo(3,4-C) furan from mahogany (Swietenia Macrophylla King) seed significantly reduces glucose and malondialdehyde levels in diabetic wistar rats. Bali Med J. 2019;8(2):570-5. https://doi.org/10.15562/bmj. v8i2.1227

37. Prasetyastuti $P$, Sunarti $S$, Sadewa $A H$, Mustofa M. Effect of 7-hydroxy-2-(4-hydroxy-3-methoxy-phenyl)- chroman-4-one (Swietenia macrophylla king seed) on retinol binding protein-4 and phosphoenolpyruvate carboxykinase gene expression in type 2 diabetic rats. Rom J Diabetes Nutr Metab Dis. 2016;23(3):255-65. https://doi.org/10.1515/rjdnmd-2016-0030

38. Prasetyastuti $P$, Sunarti $S$, Sadewa AH, Mursiti $S$, Mustofa M. Effects of 7-hydroxy-2-(4-hydroxy-3-methoxyphenyl)chromen-4 -one from Swietenia macrophylla King seed on oxidized LDL, HOMA beta and Glucagon like peptide 1 (GLP-1) gene expression in Type 2 diabetic rats. Asian J Biochem. 2017;12(3):85-90. https://doi.org/10.3923/ajb.2017.85.90

39. Singh D, Gawande DY, Singh T, Poroikov V, Goel RK.
Revealing pharmacodynamics of medicinal plants using in silico approach: A case study with wet lab validation. Comput Biol Med. 2014;47(1):1-6. https://doi.org/10.1016/j. compbiomed.2014.01.003

PMid:24503467

40. Yi F, Li L, Jia XL, Meng H, Mao DY, Bo LH, et al. In silico approach in reveal traditional medicine plants pharmacological material basis. Chin Med. 2018;13(1):1-20. https://doi.org/10.1186/ s13020-018-0190-0

41. Fukuen $S$, Iwaki $M$, Yasui $A$, Makishima $M$, Matsuda $M$, Shimomura I. Sulfonylurea agents exhibit peroxisome proliferator-activated receptor $\gamma$ agonistic activity. J Biol Chem. 2005;280(25):23653-9. https://doi.org/10.1074/jbc.m412113200 PMid: 15764598

42. Scarsi M, Podvinec M, Roth A, Hug H, Kersten S, Albrecht $H$, et al. Sulfonylureas and glinides exhibit peroxisome proliferatoractivated receptor $\gamma$ activity: A combined virtual screening and biological assay approach. Mol Pharmacol. 2007;71(2):398-406. https://doi.org/10.1124/mol.106.024596 PMid:17082235

43. Guasch L, Sala E, Mulero M, Valls C, Salvadó MJ, Pujadas G, et al. Identification of PPARgamma partial agonists of natural origin (II): In silico prediction in natural extracts with known antidiabetic activity. PLoS One. 2013;8(2):1-10. https://doi. org/10.1371/journal.pone.0055889

PMid:23405231

44. Sahebkar A, Chew GT, Watts GF. New peroxisome proliferatorActivated receptor agonists: Potential treatments for atherogenic dyslipidemia and non-alcoholic fatty liver disease. Expert Opin Pharmacother. 2014;15(4):493-503. https://doi.org/10.1517/146 56566.2014.876992 PMid:24428677

45. Staels B, Fruchart JC. Therapeutic roles of peroxisome proliferator-activated receptor agonists. Diabetes. 2005;54(8):2460-70. https://doi.org/10.2337/diabetes.54.8.2460 PMid: 16046315

46. Jain N, Bhansali S, Kurpad AV, Hawkins M, Sharma A, Kaur S, et al. Effect of a dual PPAR $\alpha / \gamma$ agonist on insulin sensitivity in patients of Type 2 diabetes with hypertriglyceridemia-randomized double-blind placebo-controlled trial. Sci Rep. 2019;9(1):1-9. https://doi.org/10.1038/s41598-019-55466-3

47. Erion DM, Park HJ, Lee HY. The role of lipids in the pathogenesis and treatment of Type 2 diabetes and associated co-morbidities. BMB Rep. 2016;49(3):139-48. https://doi.org/10.5483/ bmbrep.2016.49.3.268 PMid:26728273

48. Tumova J, Andel M, Trnka J. Excess of free fatty acids as a cause of metabolic dysfunction in skeletal muscle. Physiol Res. 2016;65(2):193-207. https://doi.org/10.33549/ physiolres.932993 PMid:26447514

49. Morón EB, Jiménez ZA, de Marañón AM, lannantuoni $F$, López IE, Domènech SL, et al. Relationship between oxidative stress, ER stress, and inflammation in Type 2 diabetes: The battle continues. J Clin Med. 2019;8(9):1-22. https://doi. org/10.3390/jcm8091385

PMid:31487953

50. Mishra BK, Banerjee BD, Agrawal V, Madhu SV. Association of PPAR $\gamma$ gene expression with postprandial hypertriglyceridaemia and risk of Type 2 diabetes mellitus. Endocrine. 2020;68(3):549-56. https://doi.org/10.1007/ s12020-020-02257-w PMid:32180115

51. Aghamohammadzadeh N, Niafar M, Dalir Abdolahinia E, Najafipour F, Gharebaghi SM, Adabi K, et al. The effect of 
pioglitazone on weight, lipid profile and liver enzymes in Type 2 diabetic patients. Ther Adv Endocrinol Metab. 2015;6(2):56-60. https://doi.org/10.1177/2042018815574229

PMid:25941563

52. TabassumA,MahboobT.Roleofperoxisomeproliferator-activated receptor-gamma activation on visfatin, advanced glycation end products, and renal oxidative stress in obesity-induced Type 2 diabetes mellitus. Hum Exp Toxicol. 2018;37(11):1187-98. https://doi.org/10.1177/0960327118757588

PMid:29441829

53. TahraniAA, BarnettAH, Bailey CJ.SGLT inhibitors in management of diabetes. Lancet Diabetes Endocrinol. 2013;1(2):140-51. https://doi.org/10.1016/s2213-8587(13)70050-0 PMid:24622320

54. Abbas G, Al Harrasi A, Hussain H, Hamaed A, Supuran CT. The management of diabetes mellitus-imperative role of natural products against dipeptidyl peptidase- $4, \alpha$-glucosidase and sodium-dependent glucose co-transporter 2 (SGLT2). Bioorg Chem. 2019;86:305-15. https://doi.org/10.1016/j. bioorg.2019.02.009

55. Lage OM, Ramos MC, Calisto R, Almeida E, Vasconcelos V, Vicente F. Current screening methodologies in drug discovery for selected human diseases. Mar Drugs. 2018;16(8):1-31. https://doi.org/10.3390/md16080279

PMid:30110923

56. Silvestri A, Vicente F, Vicent MJ, Stechmann B, Fecke W. Academic collaborative models fostering the translation of physiological in vitro systems from basic research into drug discovery. Drug Discov Today. 2021;26(6):1369-81. https://doi. org/10.1016/j.drudis.2021.02.024

57. Hughes JP, Rees SS, Kalindjian SB, Philpott KL. Principles of early drug discovery. $\mathrm{Br} \mathrm{J}$ Pharmacol. 2011;162(6):1239-49. https://doi.org/10.1111/j.1476-5381.2010.01127.x PMid:21091654

58. Lautaoja JH, Pekkala S, Pasternack A, Laitinen M, Ritvos O, Hulmi JJ. Differentiation of murine $\mathrm{C} 2 \mathrm{C} 12$ myoblasts strongly reduces the effects of myostatin on intracellular signaling. Biomolecules. 2020;10(5):1-24. https://doi.org/10.3390/ biom10050695

PMid:32365803

59. Wong CY, Al-Salami H, Dass CR. C2C12 cell model: Its role in understanding of insulin resistance at the molecular level and pharmaceutical development at the preclinical stage. J Pharm Pharmacol. 2020;72(12):1667-93. https://doi.org/10.1111/ jphp.13359

60. Wang L, Waltenberger B, Pferschy-Wenzig EM, Blunder M, Liu $\mathrm{X}$, Malainer $\mathrm{C}$, et al. Natural product agonists of peroxisome proliferator-activated receptor gamma (PPAR $\gamma$ ): A review. Biochem Pharmacol. 2014;92(1):73-89. https://doi. org/10.1016/j.bcp.2014.07.018

PMid:25083916

61. Fatemi N, Sanati MH, Shamsara M, Moayer F, Zavarehei MJ, Pouya A, et al. TBHP-induced oxidative stress alters microRNAs expression in mouse testis. J Assist Reprod Genet. 2014;31(10):1287-93. https://doi.org/10.1007/ s10815-014-0302-4

PMid:25141839

62. Kučera $O$, Endlicher R, Roušar $T$, Lotková H, Garnol $T$, Drahota $Z$, et al. The effect of tert -butyl hydroperoxideinduced oxidative stress on lean and steatotic rat hepatocytes in vitro. Oxid Med Cell Longev. 2014;2014:1-12. https://doi. org/10.1155/2014/752506

63. Liang F, Fang Y, Cao W, Zhang Z, Pan S, Xu X. Attenuation of tert-butyl hydroperoxide (t-BHP)-induced oxidative damage in HepG2 cells by tangeretin: Relevance of the Nrf2ARE and MAPK signaling pathways. J Agric Food Chem.
2018;66(25):6317-25. https://doi.org/10.1021/acs.jafc.8b01875 PMid:29871486

64. Giacco F, Brownlee M. Oxidative stress and diabetic complications. Circ Res. 2010;107(9):1058-70. https://doi. org/10.1161/circresaha.110.223545

PMid:21030723

65. Asmat U, Abad K, Ismail K. Diabetes mellitus and oxidative stress-a concise review. Saudi Pharm J. 2016;24(5):547-53. https://doi.org/10.1016/j.jsps.2015.03.013

PMid:27752226

66. Muthmainah M. Effect of Seeds Isolate from Swietenia macrophylla King in Type 2 Diabetic Rats Model: Molecular Study of Antidiabetic Effect of Isolate 1,4-bis-(3,4,5-Trimetoksifenil)-tetrahidro-furo(3,4-c) Furan (Translate from Indonesia Language). Surakarta: Universitas Sebelas Maret; 2019. https:// doi.org/10.26911/mid.icph.2018.05.22

67. Tangvarasittichai S. Oxidative stress, insulin resistance, dyslipidemia and Type 2 diabetes mellitus. World J Diabetes. 2015;6(3):456-80. https://doi.org/10.4239/wjd.v6.i3.456 PMid:25897356

68. Kaneto H, Katakami N, Matsuhisa M, Matsuoka TA. Role of reactive oxygen species in the progression of Type 2 diabetes and atherosclerosis. Mediators Inflamm. 2010;2010:1-11. https://doi.org/10.1155/2010/453892

PMid:20182627

69. Wang J, Wang H. Oxidative stress in pancreatic beta cell regeneration. Oxid Med Cell Longev. 2017;2017:1-9. PMid:28845211

70. Gutch M, Kumar S, Razi SM, Gupta K, Gupta A. Assessment of insulin sensitivity/resistance. Indian J Endocrinol Metab. 2015;19(1):160-4. https://doi.org/10.4103/2230-8210.146874 PMid:25593845

71. Singh Y, Garg MK, Tandon N, Marwaha RK. A Study of insulin resistance by HOMA-IR and its cut-off value to identify metabolic syndrome in urban Indian adolescents. JCRPE J Clin Res Pediatr Endocrinol. 2013;5(4):245-51. https://doi.org/10.1515/ jpem-2013-0020 PMid:24379034

72. Xiong X, Song Q, Han C, Gan W, Wei S, Liu H, et al. Insulin promotes the expression of the gluconeogenic ratelimiting enzymes phosphoenolpyruvate carboxykinase (pepck) and glucose 6-phosphatase (G6pase) through $\mathrm{PI3k} / \mathrm{Akt} / \mathrm{mTOR}$ signaling pathway in goose hepatocytes. Braz J Poult Sci. 2016;18(3):395-400. https://doi. org/10.1590/1806-9061-2015-0080

73. Zhang X, Yang S, Chen J, Su Z. Unraveling the regulation of hepatic gluconeogenesis. Front Endocrinol (Lausanne). 2019;10:1-17.

74. Stark R, Guebre-Egziabher F, Zhao X, Feriod C, Dong J, Alves TC, et al. A role for mitochondrial phosphoenolpyruvate carboxykinase (PEPCK-M) in the regulation of hepatic gluconeogenesis. J Biol Chem. 2014;289(11):7257-63. https:// doi.org/10.1074/jbc.c113.544759

PMid:24497630

75. Yu S, Meng S, Xiong M, Ma H. Phosphoenolpyruvate carboxykinase in cell metabolism: Roles and mechanisms beyond gluconeogenesis. Mol Metab. 2021;53:101257. https:// doi.org/10.1016/j.molmet.2021.101257

PMid:34020084

76. Cantley J, Ashcroft FM. Q and A: Insulin secretion and Type 2 diabetes: Why do $\beta$-cells fail? BMC Biol. 2015;13(1):33. https:// doi.org/10.1186/s12915-015-0140-6

PMid:25982967

77. Jiang Y, Wang Z, Ma B, Fan L, Yi N, Lu B, et al. GLP-1 improves 
adipocyte insulin sensitivity following induction of endoplasmic reticulum stress. Front Pharmacol. 2018;9:1168. https://doi. org/10.3389/fphar.2018.01168

PMid:30459598

78. Müller T, Finan B, Bloom S, D'Alessio D, Drucker D, Flatt $P$, et al Glucagon-like peptide 1 (GLP-1). Mol Metab. 2019;30:72-130.

PMid:31767182

79. Paternoster S, Falasca M. Dissecting the physiology and pathophysiology of glucagon-like peptide-1. Front Endocrinol (Lausanne). 2018;9:1-26. https://doi.org/10.3389/ fendo.2018.00584

PMid:30364192

80. Jeon JY, Choi SE, Ha ES, Lee HB, Kim TH, Han SJ, et al. GLP-1 improves palmitate-induced insulin resistance in human skeletal muscle via SIRT1 activity. Int J Mol Med. 2019;44(3):1161-71. https://doi.org/10.3892/ijmm.2019.4272

PMid:31524229

81. Jones B, Bloom SR, Buenaventura T, Tomas A, Rutter GA. Control of insulin secretion by GLP-1. Peptides. 2018;100:75-84. https://doi.org/10.1016/j.peptides.2017.12.013 PMid:29412835

82. Manandhar B, Ahn JM. Glucagon-like peptide-1 (GLP-1) analogs: Recent advances, new possibilities, and therapeutic implications. J Med Chem. 2015;58(3):1020-37. https://doi. org/10.1021/jm500810s

PMid:25349901

83. Ighodaro OM. Molecular pathways associated with oxidative stress in diabetes mellitus. Biomed Pharmacother. 2018;108:656-62.

PMid:30245465

84. Giri B, Dey S, Das T, Sarkar M, Banerjee J, Dash SK. Chronic hyperglycemia mediated physiological alteration and metabolic distortion leads to organ dysfunction, infection, cancer progression and other pathophysiological consequences: An update on glucose toxicity. Biomed Pharmacother. 2018;107:306-28. https://doi.org/10.1016/j.biopha.2018.07.157

85. Murphy MP. How mitochondria produce reactive oxygen species. Biochem J. 2009;417(1):1-13.

PMid:19061483

86. Rolo AP, Palmeira CM. Diabetes and mitochondrial function: Role of hyperglycemia and oxidative stress. Toxicol Appl Pharmacol. 2006;212(2):167-78. https://doi.org/10.1016/j. taap.2006.01.003

PMid: 16490224

87. Bhatti JS, Bhatti GK, Reddy PH. Mitochondrial dysfunction and oxidative stress in metabolic disorders-a step towards mitochondria based therapeutic strategies. Biochim Biophys Acta Mol Basis Dis. 2017;1863(5):1066-77. https://doi. org/10.1016/j.bbadis.2016.11.010

PMid:27836629

88. Apers DC, Willems PH, Koopman WJ, Grefte S. Interactions between mitochondrial reactive oxygen species and cellular glucose metabolism. Arch Toxicol. 2015;89(8):1209-26. https:// doi.org/10.1007/s00204-015-1520-y PMid:26047665

89. Dey A, Swaminathan K. Hyperglycemia-induced mitochondrial alterations in liver. Life Sci. 2010;87(7-8):197-214. https://doi. org/10.1016/j.lfs.2010.06.007 PMid:20600152

90. Zeng $Y$, Pan $Q$, Wang $X$, Li D, Lin $Y$, Man F, et al. Impaired mitochondrial fusion and oxidative phosphorylation triggered by high glucose is mediated by tom 22 in endothelial cells. Oxid Med Cell Longev. 2019;2019:1-23. https://doi. org/10.1155/2019/4508762
PMid:31236191

91. Ong SB, Subrayan S, Lim SY, Yellon DM, Davidson SM Hausenloy DJ. Inhibiting mitochondrial fission protects the heart against ischemia/reperfusion injury. Circulation. 2010;121(18):2012-22. circulationaha.109.906610 PMid:20421521

92. Roy S, Kim D, Sankaramoorthy A. Mitochondrial structural changes in the pathogenesis of diabetic retinopathy. J Clin Med. 2019;8(9):1363. https://doi.org/10.3390/jcm8091363 PMid:31480638

93. Lima JE, Xavier DJ, Hojo ET. Oxidative Stress, DNA Damage and Repair Pathways in Patients. In: Type 2 DiabetesFrom Pathophysiology to Modern Management. India: IntechOpen; 2019. p. 16. Available from: https://www. intechopen.com/books/type-2-diabetes-from-pathophysiologyto-modern-management/oxidative-stress-dna-damage-andrepair-pathways-in-patients-with-type-2-diabetes-mellitus. [Last assessed on 2021 Feb 05]. https://doi.org/10.5772/ intechopen.85438

94. Fujita H, Sakamoto T, Komatsu K, Fujishima H, Morii T, Narita T, et al. Reduction of circulating superoxide dismutase activity in Type 2 diabetic patients with microalbuminuria and its modulation by telmisartan therapy. Hypertens Res. 2011;34(12):1302-8. https://doi.org/10.1038/hr.2011.127

PMid:21814206

95. Solinas G, Becattini B. JNK at the crossroad of obesity, insulin resistance, and cell stress response. Mol Metab. 2017;6(2):174-84. https://doi.org/10.1016/j.molmet.2016.12.001 PMid:28180059

96. Arkan MC, Hevener AL, Greten FR, Maeda S, Li ZW, Long JM, et al. IKK- $\beta$ links inflammation to obesityinduced insulin resistance. Nat Med. 2005;11(2):191-8. https://doi.org/10.1038/nm1185

PMid: 15685170

97. Shibata T, Takaguri A, Ichihara K, Satoh K. Inhibition of the TNF- $\alpha$-induced serine phosphorylation of IRS-1 at $636 / 639$ by AICAR. J Pharmacol Sci. 2013;122(2):93-102. https://doi. org/10.1254/jphs.12270fp

PMid:23698110

98. Mandavia C, Sowers JR. Phosphoprotein phosphatase PP2A regulation of insulin receptor substrate 1 and insulin metabolic signaling. Cardiorenal Med. 2012;2(4):308-13. https://doi. org/10.1159/000343889

PMid:23381670

99. Sergi D, Naumovski N, Heilbronn LK, Abeywardena M, O'Callaghan N, Lionetti L, et al. Mitochondrial (dys)function and insulin resistance: From pathophysiological molecular mechanisms to the impact of diet. Front Physiol. 2019;10:1-20. https://doi.org/10.3389/fphys.2019.00532

PMid:31130874

100. Dutta M, Biswas UK, Chakraborty R, Banerjee P, Kumar A, Raychaudhuri U. Enhanced antioxidant enzyme activity in tissues and reduced total oxidative stress in plasma by the effect of Swietenia macrophylla king seeds in Type II diabetes rats. Int J Herb Med IJHM. 2014;1(16):31-6. https://doi.org/10.1007/ s13410-012-0109-8

101. Caimi G, Lo Presti R, Montana M, Noto D, Canino B, Averna MR, et al. Lipid peroxidation, nitric oxide metabolites, and their ratio in a group of subjects with metabolic syndrome. Oxid Med Cell Longev. 2014;2014:824756. https://doi. org/10.1155/2014/824756

PMid:24987495

102. Kumar V, Abbas AK, editor. Basic Pathology. $9^{\text {th }}$ ed. Canada: Elsevier Sounders; 2013. 
103. Shou J, Chen PJ, Xiao WH. Mechanism of increased risk of insulin resistance in aging skeletal muscle. Diabetol Metab Syndr. 2020;12(1):1-10. https://doi.org/10.1186/s13098-020-0523-x PMid:32082422

104. Kalpana K, Pugalendi KV. Antioxidative and hypolipidemic efficacy of alcoholic seed extract of Swietenia macrophylla in streptozotocin diabetic rats. J Basic Clin Physiol Pharmacol. 2011;22(1-2):11-21. https://doi.org/10.1515/jbcpp.2011.001 PMid:22865358

105. Ghemrawi R, Battaglia-Hsu SF, Arnold C. Endoplasmic reticulum stress in metabolic disorders. Cells. 2018;7(6):1-35. https://doi. org/10.20944/preprints201805.0264.v1 PMid:29921793

106. Salvadó L, Palomer X, Barroso E, Vázquez-Carrera M. Targeting endoplasmic reticulum stress in insulin resistance. Trends Endocrinol Metab. 2015;26(8):438-48. https://doi.org/10.1016/j. tem.2015.05.007

PMid:26078196

107. Flamment M, Hajduch E, Ferré P, Foufelle F. New insights into ER stress-induced insulin resistance. Trends Endocrinol Metab. 2012;23(8):381-90. https://doi.org/10.1016/j.tem.2012.06.003 PMid:22770719

108. Hasnain SZ, Prins JB, McGuckin MA. Oxidative and endoplasmic reticulum stress in $\beta$-cell dysfunction in diabetes. J Mol Endocrinol. 2016;56(2):33-54. PMid:26576641

109. Labra RV, Subiabre M, Toledo F, Pardo F, Sobrevia L. Endoplasmic reticulum stress and development of insulin resistance in adipose, skeletal, liver, and foetoplacental tissue in diabesity. Mol Aspects Med. 2019;66:49-61. https://doi. org/10.1016/j.mam.2018.11.001

PMid:30472165

110. Cernea S, Dobreanu M. Diabetes and beta cell function: From mechanisms to evaluation and clinical implications. Biochem Medica. 2013;23(3):266-80. https://doi.org/10.11613/ bm.2013.033

PMid:24266296

111. Montane J, Cadavez L, Novials A. Stress and the inflammatory process: A major cause of pancreatic cell death in Type 2 diabetes. Diabetes Metab Syndr Obes Targets Ther. 2014;7:25-34. https://doi.org/10.2147/dmso.s37649 PMid:24520198

112. Cao SS, Kaufman RJ. Endoplasmic reticulum stress and oxidative stress in cell fate decision and human disease. Antioxidants Redox Signal. 2014;21(3):396-413. https://doi. org/10.1089/ars.2014.5851

PMid:24702237

113. Katsube H, Hinami $Y$, Yamazoe $T$, Inoue $Y H$. Endoplasmic reticulum stress-induced cellular dysfunction and cell death in insulin-producing cells results in diabetes-like phenotypes in Drosophila. Biol Open. 2019;8(12):1-12. https://doi.org/10.1242/ bio. 046524

PMid:31822470

114. Suryavanshi SV, Kulkarni YA. NF- $\kappa \beta$ : A potential target in the management of vascular complications of diabetes. Front Pharmacol. 2017;8:1-12. https://doi.org/10.3389/ fphar.2017.00798

PMid:29163178

115. Liu X. Research progresses of the mechanism of insulin resistance in Type II diabetes. E3S Web Conf. 2019;78:1-6. https://doi.org/10.1051/e3sconf/20197801006

116. Brown M, Dainty S, Strudwick N, Mihai AD, Watson JN, Dendooven R, et al. Endoplasmic reticulum stress causes insulin resistance by inhibiting delivery of newly synthesized insulin receptors to the cell surface. Mol Biol Cell. 2020;31(23):2597-629. https://doi.org/10.1091/mbc. e18-01-0013

\section{PMid:32877278}

117. Rehman K, Akash MS. Mechanisms of inflammatory responses and development of insulin resistance: How are they interlinked? J Biomed Sci. 2016;23(1):1-18. https://doi.org/10.1186/ s12929-016-0303-y

PMid:27912756

118. Supriady H, Kamarudin MN, Chan CK, Goh BH, Kadir HA SMEAF attenuates the production of pro-inflammatory mediators through the inactivation of Akt-dependent NF-KB p38 and ERK1/2 pathways in LPS-stimulated BV-2 microglial cells. J Funct Foods. 2015;17:434-48. https://doi.org/10.1016/j. jff.2015.05.042

119. Soskic SS. Regulation of inducible nitric oxide synthase (iNOS) and its potential role in insulin resistance, diabetes and heart failure. Open Cardiovasc Med J. 2011;5(1):153-63. https://doi. org/10.2174/1874192401105010153

PMid:21792376

120. Ropelle ER, Pauli JR, Cintra DE, Da Silva AS, De Souza CT, Guadagnini D, et al. Targeted disruption of inducible nitric oxide synthase protects against aging, S-nitrosation, and insulin resistance in muscle of male mice. Diabetes. 2013;62(2):466-70. https://doi.org/10.2337/db12-0339 PMid:22991447

121. Coll T, Palomer X, Blanco-Vaca F, Escolà-Gil JC, Sánchez RM, Laguna JC, et al. Cyclooxygenase 2 inhibition exacerbates palmitate-induced inflammation and insulin resistance in skeletal muscle cells. Endocrinology. 2010;151(2):537-48. https://doi. org/10.1210/en.2009-0874

PMid:20022932

122. Ma X, Chen Z, Wang L, Wang G, Wang Z, Dong XB, et al. The pathogenesis of diabetes mellitus by oxidative stress and inflammation: Its inhibition by berberine. Front Pharmacol. 2018;9:1-13. https://doi.org/10.3389/fphar.2018.00782 PMid:30100874

123. Qi J, Wu Q, Cheng Q, Chen X, Zhu M, Miao C. High glucose induces endothelial COX2 and iNOS expression via inhibition of monomethyltransferase SETD8 expression. J Diabetes Res. 2020;2020:1-10. https://doi.org/10.1155/2020/2308520

124. Huang X, Liu G, Guo J, Su ZQ. The PI3K/AKT pathway in obesity and Type 2 diabetes. Int J Biol Sci. 2018;14(11):1483-96. https:// doi.org/10.7150/ijbs. 27173 PMid:30263000

125. Feng J, Lu S, Ou B, Liu Q, Dai J, Ji C, et al. The role of JNK signaling pathway in obesity-driven insulin resistance. Diabetes Metab Syndr Obes Targets Ther. 2020;13:1399-406. https://doi. org/10.2147/dmso.s236127 PMid:32425571

126. Yang R, Wang L, Xie J, Li X, Liu S, Qiu S, et al. Treatment of Type 2 diabetes mellitus via reversing insulin resistance and regulating lipid homeostasis in vitro and in vivo using cajanonic acid A. Int J Mol Med. 2018;42(5):2329-42. https:// doi.org/10.3892/ijmm.2018.3836

PMid:30226559

127. Mackenzie RW, Elliott BT. Akt/PKB activation and insulin signaling: A novel insulin signaling pathway in the treatment of Type 2 diabetes. Diabetes Metab Syndr Obes. 2014;7:55-64. https://doi.org/10.2147/dmso.s48260

PMid:24611020

128. Saini V. Molecular mechanisms of insulin resistance in Type 2 diabetes mellitus. World J Diabetes. 2010;1(3):68-75. https:// doi.org/10.4239/wjd.v1.i3.68

PMid:21537430 
129. Tikhanovich I, Cox J, Weinman SA. Forkhead box class O transcription factors in liver function and disease. J Gastroenterol Hepatol. 2013;28(1):125-31. https://doi.org/10.1111/jgh.12021 PMid:23855308

130. Boughanem H, Mulero AC, Gómez MM, Sánchez LG, Cardona F, Tinahones FJ, et al. Transcriptional Analysis of FOXO1, C/ EBP- $\alpha$ and PPAR- $\gamma 2$ genes and their association with obesityrelated insulin resistance. Genes (Basel). 2019;10(706):1-14. https://doi.org/10.3390/genes10090706

PMid:31547433

131. Ren W, Cheema S, Du K. The association of ClipR-59 protein with AS160 modulates AS160 protein phosphorylation and adipocyte Glut4 protein membrane translocation. J Biol Chem. 2012;287(32):26890-900. https://doi.org/10.1074/jbc. m112.357699 PMid:22689584

132. Guo S. Insulin signaling, resistance, and metabolic syndrome: Insights from mouse models into disease mechanisms. J Endocrinol. 2014;220(2):1-23. https://doi.org/10.1530/joe-13-0327 PMid:24281010

133. Russo B, Picconi F, Malandrucco I, Frontoni S. Flavonoids and insulin-resistance: From molecular evidences to clinical trials. Int J Mol Sci. 2019;20:1-18. https://doi.org/10.3390/ijms20092061 PMid:31027340

134. Wu J, Cheng D, Liu L, Lv Z, Liu K. TBC1D15 affects glucose uptake by regulating GLUT4 translocation. Gene. 2019;683:210-5. https://doi.org/10.1016/j.gene.2018.10.025 PMid:30316925

135. Chen LC, Liao HR, Chen PY, Kuo WL, Chang TH, Sung PJ, et al. Limonoids from the seeds of Swietenia macrophylla and their anti-inflammatory activities. Molecules. 2015;20(10):18551-64. https://doi.org/10.3390/molecules201018551 PMid:26473818

136. Assmann TS, Brondani LA, Bouças AP, Rheinheimer J, de Souza $\mathrm{BM}$, Canani LH, et al. Nitric oxide levels in patients with diabetes mellitus: A systematic review and meta-analysis. Nitric Oxide Biol Chem. 2016;61:1-9. https://doi.org/10.1016/j.niox.2016.09.009 PMid:27677584

137. Levine AB, Punihaole D, Levine TB. Characterization of the role of nitric oxide and its clinical applications. Cardiology. 2012;122(1):55-68. https://doi.org/10.1159/000338150 PMid:22722323

138. Chen Y, Ruan J, Sun F, Wang H, Yang S, Zhang Y, et al. Antiinflammatory limonoids from cortex dictamni. Front Chem. 2020;8:1-12. https://doi.org/10.3389/fchem.2020.00073 PMid:32185157

139. Magallanes BO, Campos ON, Chaverri JP, Mata R. Hypoglycemic and antihyperglycemic effects of phytopreparations and limonoids from Swietenia humilis. Phytochemistry. 2015;110:111-9. https:// doi.org/10.1016/j.phytochem.2014.11.004 PMid:25534951

140. Sarian MN, Ahmed QU, Mat So'Ad SZ, Alhassan AM, Murugesu S, Perumal V, et al. Antioxidant and antidiabetic effects of flavonoids: A structure-activity relationship based study. Biomed Res Int. 2017;2017:8386065. https://doi. org/10.1155/2017/8386065

PMid:29318154

141. Gothai S, Ganesan P, Park SY, Fakurazi S, Choi DK, Arulselvan P. Natural phyto-bioactive compounds for the treatment of Type 2 diabetes: Inflammation as a target. Nutrients. 2016;8(461):1-28. https://doi.org/10.3390/nu8080461

PMid:27527213
142. Chen J, Mangelinckx S, Adams A, Wang ZT, Li WL, De Kimpe N. Natural flavonoids as potential herbal medication for the treatment of diabetes mellitus and its complications. Nat Prod Commun. 2015;10(1):187-200. https://doi. org/10.1177/1934578x1501000140 PMid:25920244

143. Fu Z, Zhang W, Zhen W, Lum H, Nadler J, Bassaganya-Riera J, et al. Genistein induces pancreatic $\beta$-cell proliferation through activation of multiple signaling pathways and prevents insulindeficient diabetes in mice. Endocrinology. 2010;151(7):3026-37. https://doi.org/10.1210/en.2009-1294 PMid:20484465

144. Huang $\mathrm{Y}$, Zhou $\mathrm{T}$, Zhang $\mathrm{Y}$, Huang $\mathrm{H}$, Ma $\mathrm{Y}, \mathrm{Wu} \mathrm{C}$, et al Antidiabetic activity of a Flavonoid-rich extract from flowers of Wisteria sinensis in Type 2 diabetic mice via activation of the IRS-1/PI3K/Akt/GLUT4 pathway. J Funct Foods. 2021;77:1-12. https://doi.org/10.1016/j.jff.2020.104338

145. Jiang S, Xu L, Xu Y, Guo Y, Wei L, Li X, et al. Antidiabetic effect of Momordica charantia saponins in rats induced by high-fat diet combined with STZ. Electron J Biotechnol. 2020;43:41-7. https://doi.org/10.1016/j.ejbt.2019.12.001

146. Zhang H, Xu J, Wang M, Xia X, Dai R, Zhao Y. Steroidal saponins and sapogenins from fenugreek and their inhibitory activity against $\alpha$-glucosidase. Steroids. 2020;161:1-7. https:// doi.org/10.1016/j.steroids.2020.108690

147. Xu J, Wang S, Feng T, Chen Y, Yang G. Hypoglycemic and hypolipidemic effects of total saponins from Stauntonia chinensis in diabetic db/db mice. J Cell Mol Med. 2018;22(12):6026-38. https://doi.org/10.1111/jcmm.13876

PMid:30324705

148. Mendes MF, David I, Bogle L. Evaluation of the effects and mechanisms of bioactive components present in hypoglycemic plants. Int J Chem Biomol Sci. 2015;1(3):167-78.

149. Elekofehinti OO. Saponins: Anti-diabetic principles from medicinal plants-a review. Pathophysiology. 2015;22(2):95-103. https://doi.org/10.1016/j.pathophys.2015.02.001

PMid:25753168

150. Nalbantsoy A, Karabay Y, Sayim F, Deliloglu GI, Gocmen B, Arikan $\mathrm{H}$, et al. Determination of in vivo toxicity and in vitro cytotoxicity of venom from the Cypriot blunt-nosed viper Macrovipera lebetina lebetina and antivenom production. J Venom Anim Toxins Incl Trop Dis. 2012;18(2):208-16. https:// doi.org/10.1590/s1678-91992012000200011

151. Syaiful RH. The effect of 1,4-bis-(3,4,5-trimetoksi-fenil)tetrahidrofuro $(3,4 \mathrm{c})$ Furan Which Isolated from the Seed Extract of Swietenia macrophylla King on cell Viability: Exploration on Cell Vero's DNA (Translate from Indonesia Language). Yogyakarta: Universitas Gadjah Mada; 2016.

152. Fielden MR, Kolaja KL. The role of early in vivo toxicity testing in drug discovery toxicology. Expert Opin Drug Saf. 2008;7(2):107-10. https://doi.org/10.1517/14740338.7.2.107 PMid: 18324874

153. Balijepalli MK, Suppaiah V, Chin AM, Buru AS, Sagineedu SR, Pichika MR. Acute oral toxicity studies of Swietenia macrophylla seeds in sprague dawley rats. Pharmacognosy Res. 2015;7(1):38-44. https://doi.org/10.4103/0974-8490.147197 PMid:25598633

154. Sahgal G, Ramanathan S, Sasidharan S, Mordi MN, Ismail S, Mansor SM. Brine shrimp lethality and acute oral toxicity studies on Swietenia mahagoni (Linn.) Jacq. seed methanolic extract. Pharmacogn Res. 2010;2(4):215-20. https://doi. org/10.4103/0974-8490.69107

PMid:21808570 